Prepared in cooperation with the City of Norman, Oklahoma

\title{
Pilot Study of Natural Attenuation of Arsenic in Well Water Discharged to the Little River Above Lake Thunderbird, Norman, Oklahoma, 2012
}

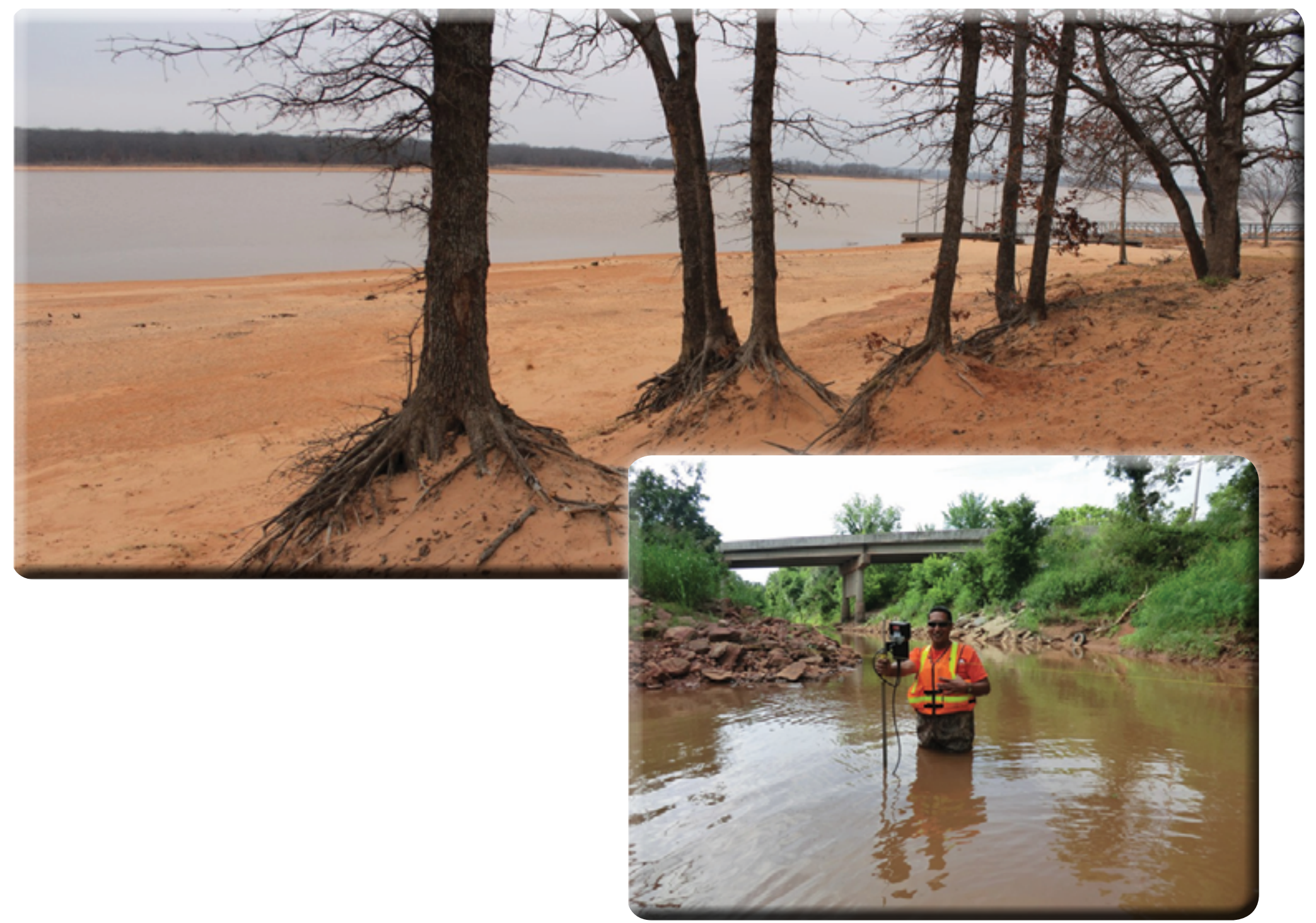

Scientific Investigations Report 2013-5055 


\section{Front cover:}

Top, Trees on the normal shoreline of Lake Thunderbird near Norman, Oklahoma, showing diminished lake levels, February 2013 (photograph by Stanley T. Paxton).

Bottom, U.S. Geological Survey hydrologist Samuel H. Rendon measuring streamflow in the Little River near Norman, Oklahoma, May 2012 (photograph by Kevin A. Smith).

\section{Back cover:}

Top, Little River near Norman, Oklahoma, May 2012 (photograph by Samuel H. Rendon).

Bottom right, Water-quality sampling at City of Norman well, May 2012 (photograph by Stanley T. Paxton).

Bottom left, U.S. Geological Survey hydrologic technician Kevin A. Smith measuring water quality in the Little River near Norman, Oklahoma, May 2012 (photograph by Samuel H. Rendon). 


\section{Pilot Study of Natural Attenuation of Arsenic in Well Water Discharged to the Little River Above Lake Thunderbird, Norman, Oklahoma, 2012}

By William J. Andrews, Jason R. Masoner, Samuel H. Rendon, Kevin A. Smith, James R. Greer, and Logan A. Chatterton

Prepared in cooperation with the City of Norman, Oklahoma

Scientific Investigations Report 2013-5055 


\title{
U.S. Department of the Interior \\ SALLY JEWELL, Secretary
}

\author{
U.S. Geological Survey \\ Suzette M. Kimball, Acting Director
}

U.S. Geological Survey, Reston, Virginia: 2013

For more information on the USGS - the Federal source for science about the Earth, its natural and living resources, natural hazards, and the environment, visit http://www.usgs.gov or call 1-888-ASK-USGS.

For an overview of USGS information products, including maps, imagery, and publications, visit http://www.usgs.gov/pubprod

To order this and other USGS information products, visit http://store.usgs.gov

Any use of trade, firm, or product names is for descriptive purposes only and does not imply endorsement by the U.S. Government.

Although this information product, for the most part, is in the public domain, it also may contain copyrighted materials as noted in the text. Permission to reproduce copyrighted items must be secured from the copyright owner.

Suggested citation:

Andrews, W.J., Masoner, J.R., Rendon, S.H., Smith, K.A., Greer, J.R., and Chatterton, L.A., 2013, Pilot study of natural attenuation of arsenic in well water discharged to the Little River above Lake Thunderbird, Norman, Oklahoma, 2012: U.S. Geological Survey Scientific Investigations Report 2013-5055, 31 p., http://pubs.usgs.gov/sir/2013/5055/. 


\section{Acknowledgments}

The authors thank Scott Aynes, Chris Mattingly, and Mark Daniels of the City of Norman for their assistance and encouragement during this study. 



\section{Contents}

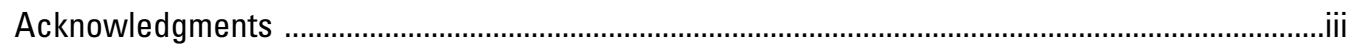

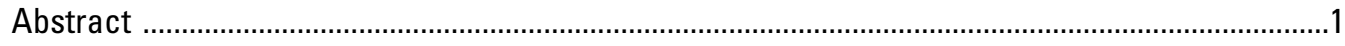

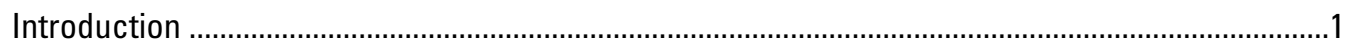

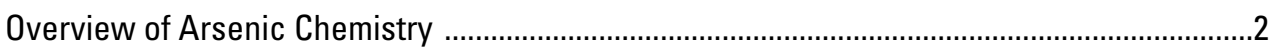

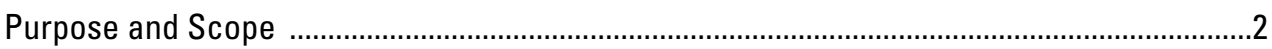

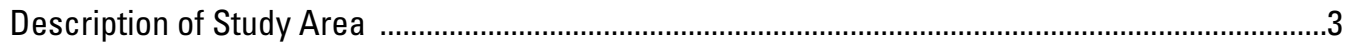

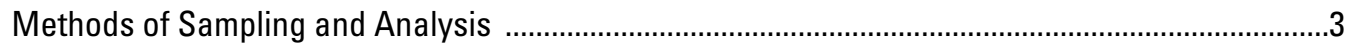

Sample Collection and Measurement of Well Discharge and Streamflow .............................3

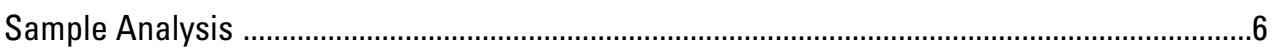

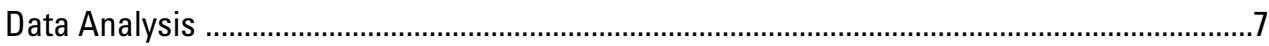

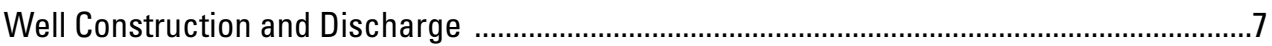

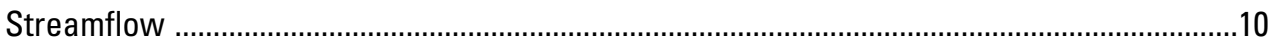

Attenuation of Arsenic and Selected Trace Elements …….......................................................11

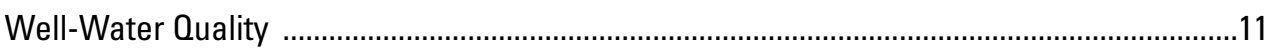

Surface-Water Quality .....................................................................................................11

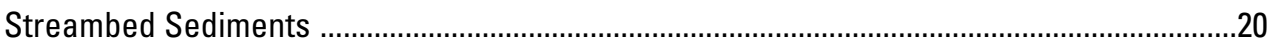

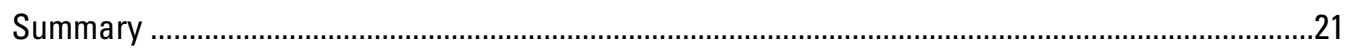

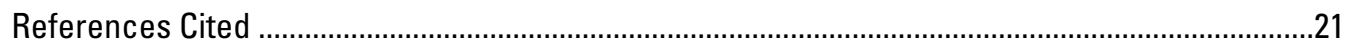

Appendixes

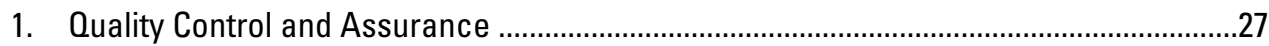

2. Stream Distances, Moving-Average Stream Velocities, and Arrival Times from the Upstream Streamflow-Gaging Station (12th Avenue Northwest) Water-Quality Sampling of the Little River near Norman, Oklahoma, May 2012 .....................................29

\section{Figures}

1. Map showing location of the central Oklahoma aquifer and groundwaterarsenic concentrations measured in the aquifer, 1977-2004

2. Map showing study area and sites sampled in or near Norman, Oklahoma, April-June 2012

3. Graph showing pumping rates for six city wells, Norman, Oklahoma, May 7-18, 2012

4. Graph showing streamflow measured at a streamflow-gaging station and daily precipitation in or near Norman, Oklahoma, April-June 2012

5. Graphs showing concentrations of selected trace elements with time discharged at six city wells in Norman, Oklahoma, May 7-18, 2012

6. Graph showing arsenic concentration and $\mathrm{pH}$ values in water samples collected from six city wells in Norman, Oklahoma, May 7-18, 2012

7. Barchart showing dissolved arsenic loads produced by six city wells in Norman, Oklahoma, May 7-18, 2012

8. Graphs showing dissolved arsenic concentrations, loads, and yields, and daily precipitation at four sites on the Little River sampled in or near Norman, Oklahoma, April-June 2012 
9. Graphs showing dissolved arsenic concentrations with concentrations of chromium, selenium, and vanadium in surface-water samples collected at four sites on the Little River in or near Norman, Oklahoma, April-June 2012

10. Graph showing estimated traveltimes of surface water from the Little River at 12th Avenue Northwest near Norman, Oklahoma, streamflow-gaging station to three downstream streamflow-gaging stations in and near Norman, Okla., May 2012

11. Graph showing estimated cumulative arsenic load discharged from six city wells and two streamflow-gaging stations on the Little River in or near Norman, Oklahoma, April 16-June 1, 2012

12. Boxplots showing distributions of selected trace-element concentrations in streambed sediments collected before and after well discharges to the Little River at nine sites in or near Norman, Oklahoma, April-June 2012

\section{Tables}

1. Groundwater, surface-water, and streambed-sediment sample site locations in or near Norman Oklahoma, April-June 2012

2. Physical properties and constituents analyzed in well water, surface water, and streambed sediment in or near Norman, Oklahoma, April-June 2012

3. Selected characteristics of city wells discharged to the Little River in Norman, Oklahoma, May 7-18, 2012

4. Initial and final amount of discharge and percentage change in discharge rate for the six city wells in Norman, Oklahoma, May 7-18, 2012

5. Mean discharges of the six city wells in Norman, Oklahoma, May 7-18, 2012

6. Selected characteristics of surface-water sites sampled in or near Norman, Oklahoma, April-June 2012

7. Instantaneous stream velocities by date, time, and location for surface-watersampling sites in or near Norman, Oklahoma, May 8-22, 2012

8. Stream-interval lengths and 2-point or 3-point moving-average stream velocities in each interval used to calculate arrival times for surface-water sampling dates of the Little River in or near Norman, Oklahoma, May 8-22, 2012

9. Summary statistics of dissolved concentrations of selected trace elements in 24 samples of water discharged by six city wells in Norman, Oklahoma, May 7-18, 2012

10. Dissolved concentrations of selected arsenic types in water samples collected from six city wells in Norman, Oklahoma, May 18, 2012

11. Coefficient of determination $\left(r^{2}\right)$ of linear regressions of dissolved concentrations of selected trace elements in 30 water samples collected at four sites on the Little River in or near Norman, Oklahoma, April-June 2012

12. Sampling dates and times shown with calculated arrival dates and traveltimes downstream and corresponding samples from the Little River at 12th Avenue Northwest near Norman, Oklahoma, streamflow-gaging station, May 2012

13. Two-sided Wilcoxon rank-sum test statistics comparing the trace-element content of streambed-sediment samples collected before and after well-water discharge to the Little River, April-May 2012, at nine sites in or near Norman, Oklahoma 


\section{Conversion Factors}

Inch/Pound to SI

\begin{tabular}{lcl}
\hline \multicolumn{1}{c}{ Multiply } & By & \multicolumn{1}{c}{ To obtain } \\
\hline inch (in.) & Length & \\
inch (in.) & 2.54 & centimeter $(\mathrm{cm})$ \\
foot (ft) & 25.4 & millimeter $(\mathrm{mm})$ \\
mile (mi) & 0.3048 & meter $(\mathrm{m})$ \\
& 1.609 & kilometer $(\mathrm{km})$ \\
\hline square mile $\left(\mathrm{mi}^{2}\right)$ & Area & square $\mathrm{kilometer}\left(\mathrm{km}^{2}\right)$ \\
\hline & 2.590 & \\
\hline gallon $($ gal) & Volume & liter $(\mathrm{L})$ \\
\hline & 3.785 & meter per day $(\mathrm{m} / \mathrm{d})$ \\
\hline foot per day $(\mathrm{ft} / \mathrm{d})$ & Flow rate & cubic meter per second $\left(\mathrm{m}^{3} / \mathrm{s}\right)$ \\
cubic foot per second $(\mathrm{ft} / \mathrm{s})$ & 0.3048 & liter per second $(\mathrm{L} / \mathrm{s})$ \\
\hline gallon per minute $(\mathrm{gal} / \mathrm{min})$ & 0.02832 & \\
\hline & 0.06309 & kilogram $(\mathrm{kg})$ \\
\hline pound, avoirdupois $(\mathrm{lb})$ & Mass & \\
\hline
\end{tabular}

SI to Inch/Pound

\begin{tabular}{|c|c|c|}
\hline Multiply & By & To obtain \\
\hline \multicolumn{3}{|c|}{ Length } \\
\hline meter $(\mathrm{m})$ & 3.281 & foot $(\mathrm{ft})$ \\
\hline kilometer (km) & 0.6214 & mile (mi) \\
\hline \multicolumn{3}{|c|}{ Area } \\
\hline square kilometer $\left(\mathrm{km}^{2}\right)$ & 247.1 & acre \\
\hline square kilometer $\left(\mathrm{km}^{2}\right)$ & 0.3861 & square mile $\left(\mathrm{mi}^{2}\right)$ \\
\hline \multicolumn{3}{|c|}{ Volume } \\
\hline liter $(\mathrm{L})$ & 0.2642 & gallon (gal) \\
\hline \multicolumn{3}{|c|}{ Mass } \\
\hline kilogram (kg) & 2.205 & pound avoirdupois (lb) \\
\hline
\end{tabular}

Temperature in degrees Celsius $\left({ }^{\circ} \mathrm{C}\right)$ may be converted to degrees Fahrenheit $\left({ }^{\circ} \mathrm{F}\right)$ as follows:

${ }^{\circ} \mathrm{F}=\left(1.8 \times{ }^{\circ} \mathrm{C}\right)+32$

Temperature in degrees Fahrenheit $\left({ }^{\circ} \mathrm{F}\right)$ may be converted to degrees Celsius $\left({ }^{\circ} \mathrm{C}\right)$ as follows:

${ }^{\circ} \mathrm{C}=\left({ }^{\circ} \mathrm{F}-32\right) / 1.8$

Vertical coordinate information is referenced to the North American Vertical Datum of 1988 (NAVD 88).

Horizontal coordinate information is referenced to the North American Datum of 1983 (NAD 83).

Elevation, as used in this report, refers to distance above the vertical datum.

Concentrations of chemical constituents in water are given either in milligrams per liter (mg/L) or micrograms per liter $(\mu \mathrm{g} / \mathrm{L})$. 



\title{
Pilot Study of Natural Attenuation of Arsenic in Well Water Discharged to the Little River Above Lake Thunderbird, Norman, Oklahoma, 2012
}

\author{
By William J. Andrews, Jason R. Masoner, Samuel H. Rendon, Kevin A. Smith, James R. Greer, and \\ Logan A. Chatterton
}

\section{Abstract}

The City of Norman, Oklahoma, wanted to augment its water supplies to meet the needs of an increasing population. Among the city's potential water sources are city wells that produce water that exceeds the 10 micrograms per liter primary drinking-water standard for arsenic. The City of Norman was interested in investigating low-cost means of using natural attenuation to remove arsenic from well water and augment the water supply of Lake Thunderbird, the primary water source for the city. The U.S. Geological Survey, in cooperation with the City of Norman, conducted a preliminary investigation (pilot study) to determine if discharge of water from those wells into the Little River over a 12-day period would reduce arsenic concentrations through natural-attenuation processes. Water in the Little River flows into Lake Thunderbird, the principal water source for the city, so the discharged well water would improve the water balance of that reservoir.

During this pilot study, 150-250 gallons per minute from each of six city wells were discharged to the Little River over a 12-day period. Water-quality samples were collected from the wells during discharge and from the river before, during, and after well discharges. Streambed-sediment samples were collected at nine sites in the river before and after the well-discharge period. Water discharge from the six wells added 0.3 kilogram per day of arsenic to the river at the nearest downstream streamflow-gaging station. Dissolved arsenic concentration in the Little River at the closest downstream sampling site from the wells increased from about 4 micrograms per liter to as much as 24 micrograms per liter. Base flow in the river increased by about 1.7 cubic feet per second at the nearest downstream streamflow-gaging station. Streamflow in the river was two-thirds of that expected from the amount of water discharged from the wells because of seepage to soils and evapotranspiration of well water along drainage ways to the river. Arsenic concentrations at the nearest downstream streamflow-gaging station were less than arsenic concentrations measured in many of the well-water samples during the well-pumping period.
Arsenic concentrations, loads, and yields in the Little River generally decreased downstream from the closest streamflow-gaging station to the wells by 50 percent or more, indicating removal of about 0.25 kilogram or 0.53 pound per day of arsenic during base-flow conditions. Measured river-water arsenic concentrations near the confluence of the Little River with Lake Thunderbird were in compliance with the primary drinking-water standard. Arsenic concentrations measured at four downstream stations in the Little River also were less than established criteria set for protection of aquatic biota. After well discharges to the Little River were stopped, arsenic concentrations, loads, and yields in the river gradually decreased over 14 days to concentrations measured prior to the well-water discharges. Cumulative loads of arsenic discharged at the wells and the closest and farthest downstream streamflow-gaging stations indicated removal of about 2.5 kilograms of arsenic as well-water flowed to and down the river. Arsenic concentrations in streambed-sediment samples collected before and after the well-water discharges were not significantly different. Results of this pilot study indicate that using natural-attenuation processes to remove arsenic from water and supplement city water supplies may be a viable, relatively low-cost method for attenuating arsenic in well water and for augmenting the water supply of Lake Thunderbird.

\section{Introduction}

In January 2006, the U.S. Environmental Protection Agency (USEPA) reduced the primary drinking-water standard for arsenic from 50 to 10 micrograms per liter $(\mu \mathrm{g} / \mathrm{L})$ in response to new information about the risk of lung and bladder cancers caused by ingestion of arsenic (Morales and others, 2000). About 5 percent of public-supply water systems in the United States, serving about 11 million people, were expected to exceed the new drinking-water standard (Tiemann, 2001), including several municipal water systems that produce water from the Central Oklahoma aquifer (COA). Well water produced from parts of the COA has arsenic concentrations 
exceeding the primary drinking-water standard of $10 \mu \mathrm{g} / \mathrm{L}$ (Schlottmann and others, 1998; Smith, 2005; Smith and others, 2009; Smith and Becker, 2011; U.S. Environmental Protection Agency, 2012). Concentrations of arsenic in excess of the new primary drinking-water standard have reduced the availability of groundwater for several communities, including the rapidly growing City of Norman, Okla. (Smith, 2005).

The City of Norman, Okla., idled about one-third of its large-capacity wells in the mid-2000s because concentrations of arsenic in water from those wells exceeded the primary drinking-water standard and the high cost of removing arsenic from that water (Smith, 2005). The principal water source for Norman is Lake Thunderbird (which supplied 2.96 billion gallons in 2010), which is supplemented by water pumped from wells (about 1.30 billion gallons in 2010) to supply approximately 110,000 residents with water (Bryan Hapke, City of Norman, written commun., 2012; Steven Barker, Oklahoma Department of Commerce, written commun., 2011). Increased demand for water by the city and recent droughts have lowered the lake level, limiting the amount of water that the city water utility can pump from Lake Thunderbird.

The City of Norman was interested in investigating low-cost means of using natural attenuation to remove arsenic from well water and augment the water supply of Lake Thunderbird. One option was to pump water with high arsenic concentration from selected city wells into the Little River, a major tributary to Lake Thunderbird, with expectations that arsenic in the added water would be diluted by river water and removed by sorption of aqueous arsenic to streambed sediments. If that method was successful, the city could use water from several idle wells to augment the supply of water in Lake Thunderbird with minimal infrastructure changes. Supplementing water in Lake Thunderbird with well-water discharges to the Little River, particularly during dry periods, would enable the city to withdraw additional water from the lake during other times of the year (Chris Mattingly, City of Norman, written commun., 2012). Results from this study may be relevant to other areas with elevated arsenic concentration in groundwater and combined groundwater/surface-water public-supply systems, though local conditions are likely to affect the extent of natural attenuation of arsenic.

\section{Overview of Arsenic Chemistry}

Arsenic is a common element in rocks of the Earth's crust and tends to be associated with iron, manganese, and aluminum minerals (Pierce and Moore, 1980; Stollenwerk, 2003). Arsenic is present in small concentrations in many hydrogeologic settings and can occur naturally in groundwater in concentrations sufficiently large to be detrimental to human health. Arsenic compounds have been used in a wide range of industrial products including medicines, herbicides, and poultry-feed supplements. Chronic ingestion of arsenic in drinking water or other substances can cause nausea and vomiting, decreased production of blood cells, abnormal heart rhythm, damage to blood vessels, fetal deformations, neurological effects, cancers, and death (Agency for Toxic Substances and Disease Registry, 2007; Eisler, 1988). The most common forms of arsenic in water are the inorganic arsenite and arsenate ions and the organic forms monomethylarsonate and dimethylarsinate (U.S. Environmental Protection Agency, 1985).

Although arsenic exists in nature in the $-3,0,+3$, and +5 valence states, only arsenic in the +3 or +5 valence states (As-III and As- $\mathrm{V}$, respectively) is common in natural waters. These valence states form the oxyanion species arsenite $\left(\mathrm{H}_{3-\mathrm{x}} \mathrm{AsO}_{3}^{-\mathrm{x}}\right)$, and arsenate $\left(\mathrm{H}_{3-\mathrm{x}} \mathrm{AsO}_{4}^{-\mathrm{x}}\right)$ (Rai and Zachara, 1984; Hem, 1985). As-III is the stable form of aqueous arsenic in moderately reduced (oxygen depleted) water, and As- $\mathrm{V}$ is the stable form of arsenic in oxic water. As-III and As-V may co-occur in water because conversions of As-III to As-V, or As-V to As-III, are slow reactions (Welch and others, 2000). Inorganic arsenic compounds generally are more toxic than organic arsenic compounds, with the As-III form of arsenic being more toxic than the As-V form (Eisler, 1988; Hughes, 2002).

The arsenate form of arsenic precipitates with or adsorbs on hydrous iron oxides, and calcium, sulfur, aluminum, and barium minerals (U.S. Environmental Protection Agency, 1980; Barringer and others, 2010). Adsorption of arsenic on naturally occurring aluminum- and iron-oxide coatings on mineral grains in the unsaturated zone was measured during groundwater recharge by Izbicki and others (2008). Such coatings are most abundant on finegrained sediments. Streambed sediments commonly contain oxides and oxyhydroxides of aluminum, iron, barium, and other trace elements that may be effective for lowering dissolved arsenic concentrations (Barringer and others, 2010). Sulfide in reduced streambed or lakebed sediments also can cause precipitation and sorption of iron compounds and arsenic (Kobayashi and Lee, 1978). Sediments of the Little River are expected to contain many of the arsenic-sorbing phases of trace metals and other cations. Accordingly, well water discharged to the Little River was expected to lose some portion of dissolved arsenic as the well water and river water contacted sediment.

\section{Purpose and Scope}

The purpose of this report is to describe results of a pilot study to investigate the potential to use the naturalattenuation capacity of the Little River to lower arsenic concentrations in water discharged from six municipal wells in Norman, Okla. This report describes analyses of well and stream discharges, water quality, and streambed-sediment chemistry for samples collected in or near the Little River from April through June 2012. 


\section{Description of Study Area}

The COA, also known as the Garber-Wellington aquifer, consists of a westward-dipping complex mixture of discontinuous mudstones, siltstones, and channelized sandstones of Permian age (Parkhurst and others, 1996). Overlying the Garber Sandstone and Wellington Formation is the Hennessey Group, a leaky confining unit that consists of mudstones and siltstones (Parkhurst and others, 1996). Sandstones in the Garber Sandstone and Wellington Formation, which underlie about 3,000 square miles in central Oklahoma (fig. 1), provide most of the groundwater withdrawn from the COA.

Large dissolved concentrations of arsenic and other trace elements in parts of the COA are attributed to mobilization from sediment that forms the aquifer in response to geochemical conditions. Trace-element concentrations tend to increase with depth in the aquifer; larger concentrations also are common in confined zones in the upper parts of the aquifer (Schlottmann and others, 1998). Increased concentrations of trace elements in the aquifer-mineral matrix are associated with goethite-cemented sandstone, mudstones, and chemically reduced zones (Schlottmann and others, 1998). Generally, oxidizing conditions and $\mathrm{pH}$ exceeding 8.5 facilitate release of arsenic, chromium, and selenium (Schlottmann and others, 1998). Given the complex stratigraphy and groundwater flow paths of the COA, adjoining layers of sandstones and siltstones can contain water of substantially different composition (Schlottmann and others, 1998; Smith, 2005; Smith and Becker, 2011). Thus, adjacent wells in the same well field can produce water with arsenic concentrations greater or less than the primary drinking-water standard.

The Little River (fig. 2) receives storm runoff and natural discharge from the COA near Norman, Okla. The four Little River water-quality and nine sediment-sampling sites sampled for this report were on the segment of the river between streamflow-gaging stations 07229451 (Little River at 12th Avenue Northwest near Norman, Okla.) and 07229480 (Little River near Franklin, Okla.), a channel distance of about 10.5 miles (fig. 2). The headwaters of the 230 -square-mile Little River watershed are north and west of Norman (fig. 1). The river, which is ephemeral in the headwaters of the watershed (upstream from the uppermost streamflow-gaging station), flows eastward and is the main tributary to Lake Thunderbird. Elm Creek (fig. 2) is a perennial tributary of the Little River, which flows southward from Lake Stanley Draper into the Little River about 0.5 mile upstream from streamflow-gaging station 07229480 . Unconsolidated streambed sediment in the channel of the Little River consists of clays, silts, and fine sands from erosion of soils weathered from bedrock of the COA, which consists of reddish-brown shales, mudstones, and sandstones containing carbonate rock fragments, feldspars, chlorite, and micas that are dissolving and iron oxides, manganese oxides, kaolinite, and quartz that are precipitating (Parkhurst and others, 1996). Groundwater in the COA is oxic, as indicated by relatively large dissolved concentrations of oxygen and nitrate and oxidized forms of arsenic, chromium, selenium, vanadium, and uranium (Parkhurst and others, 1996). The interconnection of groundwater and surface water through the streambed sediments in the hyporheic zone (the zone of mixing of groundwater and surface water in streambed and bank sediments) of this river provides opportunities for changes in water chemistry ( $\mathrm{pH}$ and redox-conditions) and granular (mineral) substrates suitable for naturally attenuating arsenic concentrations in water. The city wells pumped for this pilot study were at distances of 0.1 to 1.0 mile from the Little River (fig. 2); discharges from the wells flowed over grasslands and through small, grassed drainage ditches to the river.

\section{Methods of Sampling and Analysis}

\section{Sample Collection and Measurement of Well Discharge and Streamflow}

During April, 2012, 4 surface-water-quality and 18 streambed-sediment samples were collected from the Little River (at 4 sites and 9 sites, respectively), and 4 instantaneousdischarge measurements were made in the river using methods described in Wilde and others (2012) and Rantz and others (1982). From May 7 to 18, 2012, well-water samples were collected periodically at each well head by attaching a Teflon-tube adaptor to standard spigots and transferring the water through Teflon tubing to a preservation chamber. The preservation chamber was used to limit exposure to airborne contamination. Well-water samples were filtered in the field using 0.45 -micron pore-size disposable filters. Surface-water samples were collected from equal-width intervals across the stream channel and composited in a churn splitter. Samples were decanted from the churn to precleaned sample bottles. A peristaltic pump with Teflon tubing was used to filter surface-water samples. Water samples collected for cation and metal analyses were preserved using premeasured purified acids. Stream-discharge measurements were made coincident with collection of each water-quality sample. Physical properties of water, including temperature, specific conductance, dissolved-oxygen concentration, and $\mathrm{pH}$, were measured in the field using a YSI 556 multimeter calibrated with known standard solutions. At the wells, a flow-through cell was used to measure physical properties. At surface-water sites, the measurement probe of the multimeter was placed in the stream to measure physical properties. Streamflow-gaging stations were installed on the Little River at 12th Avenue Northwest (07229451, farthest upstream streamflow-gaging station) and at the Little River near Franklin (07229480, farthest downstream streamflow-gaging station) (fig. 2, table 1). Data from those stations were transmitted by satellite telemetery into the USGS National Water Information System (NWIS) database (U.S. Geological Survey 2012a). 


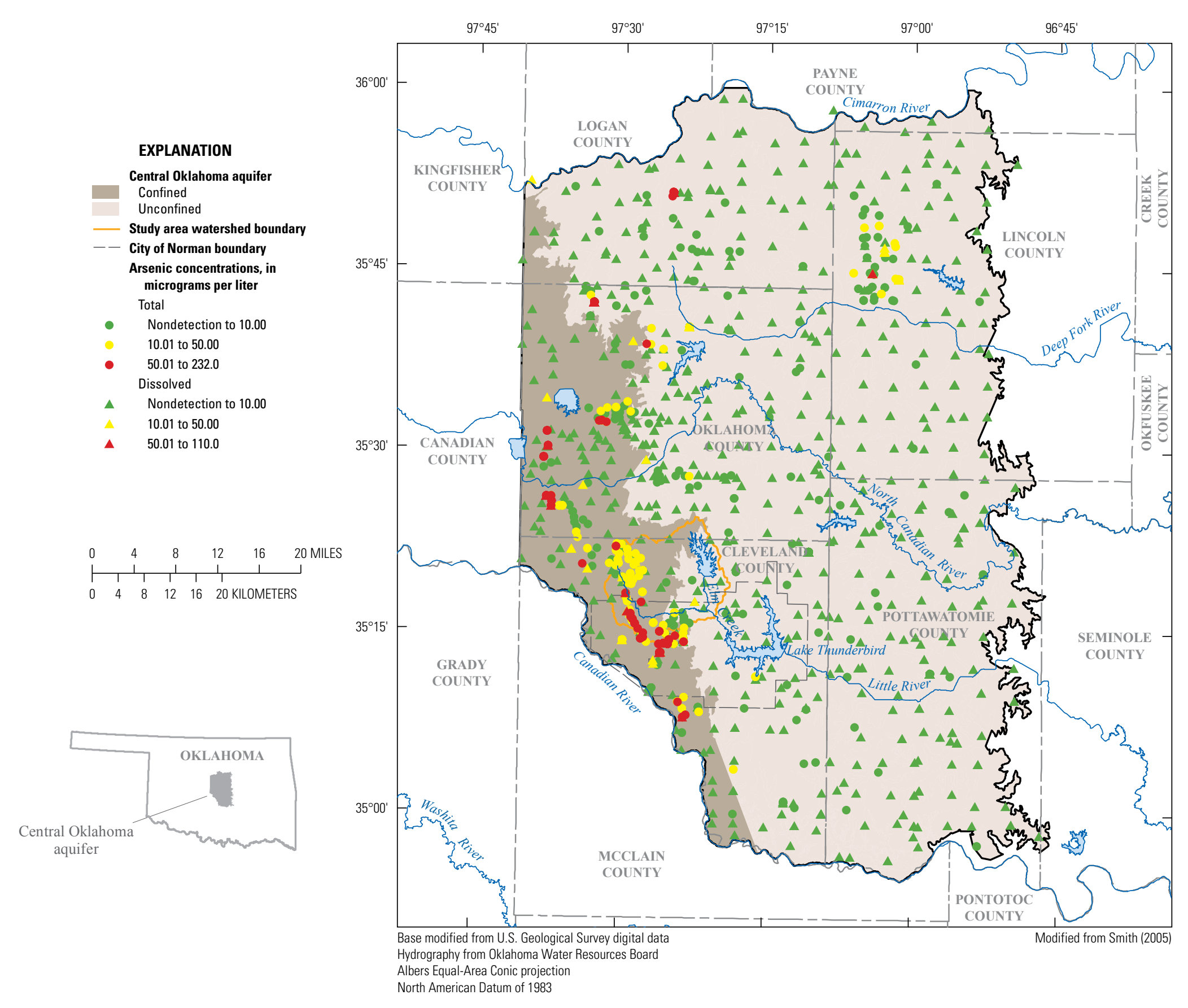

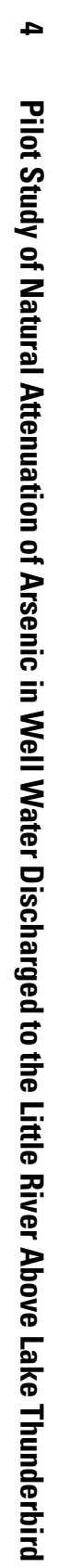

Figure 1. Location of the central Oklahoma aquifer and groundwater-arsenic concentrations measured in the aquifer, 1977-2004. 


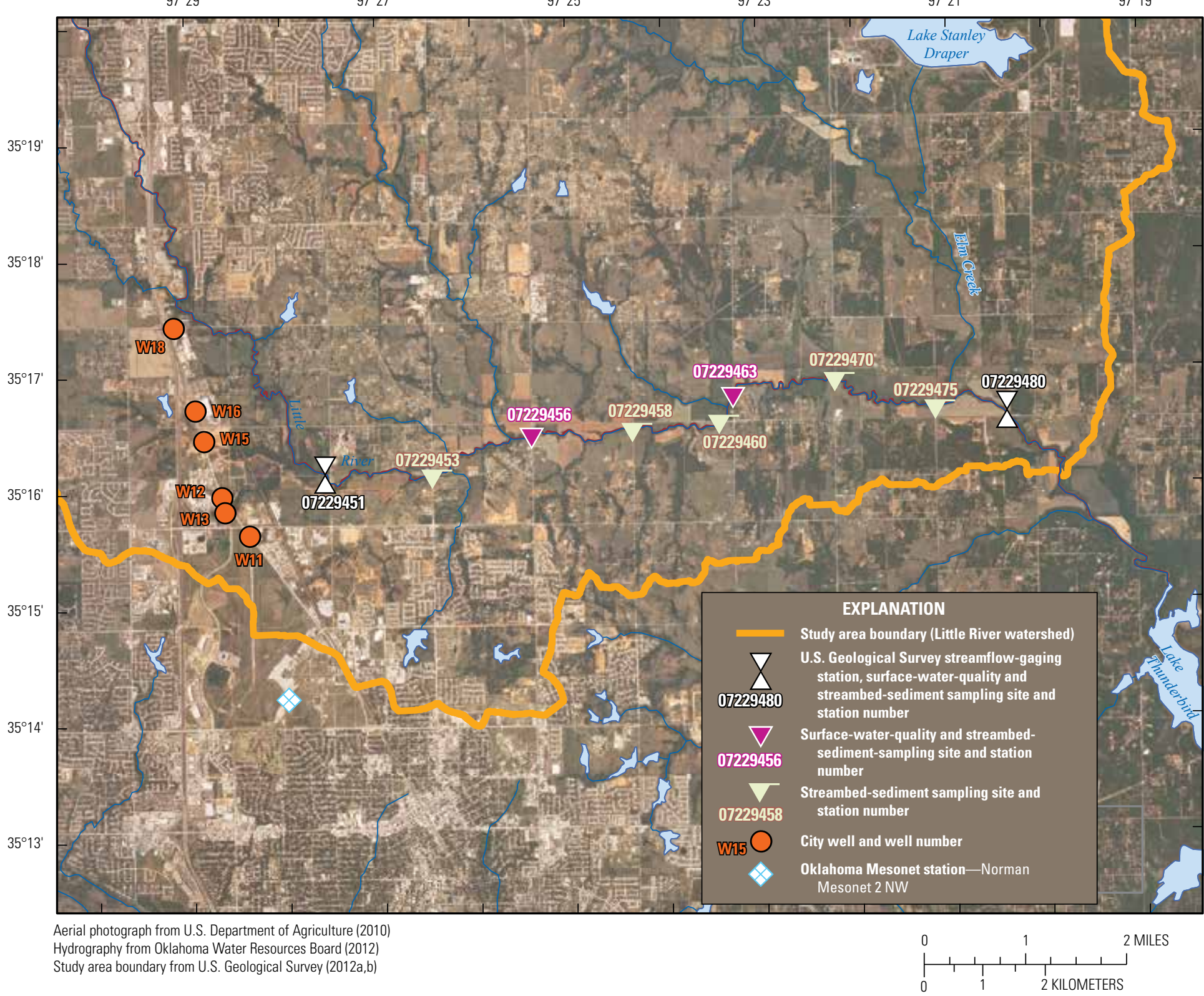

Figure 2. Study area and sites sampled in or near Norman, Oklahoma, April-June 2012. 
Table 1. Groundwater, surface-water, and streambed-sediment sample site locations in or near Norman Oklahoma, April-June 2012.

[USGS, U.S. Geological Survey; no shading for city wells, blue shading for surface-water-quality sampling sites, brown shading for streambed-sediment sampling sites]

\begin{tabular}{|c|c|c|c|}
\hline $\begin{array}{l}\text { USGS } \\
\text { site number }\end{array}$ & Site name & Site type & $\begin{array}{c}\text { Sampling } \\
\text { dates code }{ }^{1}\end{array}$ \\
\hline 351538097283401 & 09N-03W-13 BBA 1, City well 11 & City well & A \\
\hline 351559097283601 & 09N-03W-11 DAD 1, City well 12 & City well & A \\
\hline 351643097285601 & 09N-03W-02 DCA 1, City well 16 & City well & A \\
\hline 351726097290901 & 09N-03W-02 BAA 1, City well 18 & City well & A \\
\hline 07229451 & Little River at 12th Avenue Northwest near Norman, Okla. & $\begin{array}{l}\text { Streamflow-gaging station and surface- } \\
\text { water quality sampling site }\end{array}$ & $\mathrm{B}$ \\
\hline 07229456 & Little River at 12th Avenue Northeast near Norman, Okla. & Surface-water quality sampling site & $\mathrm{C}$ \\
\hline 07229451 & Little River at 12th Avenue Northwest near Norman, Okla. & Streambed-sediment sampling site & $\mathrm{D}$ \\
\hline 07229453 & Little River at Porter Avenue near Norman, Okla. & Streambed-sediment sampling site & $\mathrm{D}$ \\
\hline 07229456 & Little River at 12th Avenue Northeast near Norman, Okla. & Streambed-sediment sampling site & $\mathrm{D}$ \\
\hline 07229458 & Little River at 24th Avenue Northeast near Norman, Okla. & Streambed-sediment sampling site & $\mathrm{D}$ \\
\hline 07229460 & Little River above Lake Thunderbird near Norman, Okla. & Streambed-sediment sampling site & $\mathrm{D}$ \\
\hline 07229463 & Little River at 36th Avenue Northeast near Norman, Okla. & Streambed-sediment sampling site & $\mathrm{D}$ \\
\hline 07229470 & Little River above Elm Creek near Norman, Okla. & Streambed-sediment sampling site & $\mathrm{D}$ \\
\hline
\end{tabular}

${ }^{1}$ A, May 7, 10, 15, and 18, 2012; B, April 16, 29, 23, and 25, May 8, 14, 17, 22, 25, 29, and June 1, 2012; C, May 8, 14, 17, and 22, 2012; D, April 17-18, and May 27-28, 2012.

During a 12-day well-discharge period (May 7-18, 2012), water from six wells (Norman city wells 11, 12, 13, 15,16 , and 18) was pumped at rates of about 150 to 250 gallons per minute ( $\mathrm{gal} / \mathrm{min}$ ) and entered the Little River upstream from the streamflow-gaging station at 12th Avenue Northwest (fig. 2, table 1). During the well-discharge period, four measurements of instantaneous streamflow were made at the four surface-water sampling sites (fig. 2), six to eight measurements of well discharges were made with stopwatches and graduated buckets, and well-water-quality and surface-water-quality samples were collected. From May 22 to June 1, 2012, surface-water-quality samples were collected and streamflow was measured at each of the four water-quality sites to monitor post-well-discharge changes. A second set of 18 streambed-sediment samples was collected on May 29-31, 2012.

\section{Sample Analysis}

Well-water and surface-water-quality samples were analyzed for physical properties and constituent concentrations of filtered (dissolved) and unfiltered (total) major ions (Fishman and Friedman, 1989; Fishman, 1993), filtered trace elements, unfiltered trace elements, (Hoffman and others, 1996; Fishman and Friedman, 1989; Garbarino, 1999; Garbarino and Struzeski, 1998; Garbarino and Damrau, 2001; Garbarino and others, 2002, 2006), and arsenic compounds (Garbarino and others, 2006; table 2). Quality-control samples were collected and analyzed for quality assurance - the quantification of reproducibility and reliability of field data (appendix 1).

Streambed-sediment samples were sieved to collect sediments less than 2 millimeters in diameter. Those sieved 
Table 2. Physical properties and constituents analyzed in well water, surface water, and streambed sediment in or near Norman, Oklahoma, April-June 2012.

\begin{tabular}{lll}
\hline $\begin{array}{c}\text { Filtered and } \\
\text { unfiltered well- } \\
\text { water and surface- } \\
\text { water samples }\end{array}$ & \multicolumn{1}{c}{$\begin{array}{c}\text { Filtered surface- } \\
\text { water samples }\end{array}$} & $\begin{array}{c}\text { X-ray fluorescence } \\
\text { analysis of } \\
\text { streambed } \\
\text { sediment }\end{array}$ \\
\hline $\begin{array}{l}\text { Dissolved oxygen } \\
\text { pH, laboratory }\end{array}$ & Calcium & Aluminum \\
Specific conductance & Phosphorus & Antimony \\
Temperature & Arsenate & Arsenic \\
Aluminum & Arsenite & Barium \\
Arsenic & Dimethylarsinate & Cadmium \\
Barium & Monomethylarsonate & Copper \\
Chromium & & Iron \\
Iron & & Lead \\
Magnesium & & Manganese \\
Manganese & & Molybdenum \\
Selenium & & Nickel \\
Vanadium & & Selenium \\
& & Uranium \\
& & Vanadium \\
\hline & & \\
& & \\
& &
\end{tabular}

samples were analyzed for trace-element concentrations using a Niton XL3t 950 X-ray fluorescence (XRF) analyzer (table 2) at the USGS Oklahoma Water Science Center in Oklahoma City, Okla. Elemental concentrations determined by XRF were measures of the sediment coatings and not the elemental concentrations of the entire sediment particles, providing elemental concentrations of the reactive surface of the particles (Jenkins and others, 1995). XRF analysis was done following USEPA Method 6200 (U.S. Environmental Protection Agency, 2007). All water-quality samples were analyzed by the USGS National Water Quality Laboratory (NWQL) in Lakewood, Colorado. Stream-discharge measurements were made prior to the collection of surfacewater samples as described in Wilde and others (2012). All streamflow, water-quality, and streambed-sediment data summarized in this report are available at the USGS NWIS Web site at http://waterdata.usgs.gov/ok/nwis.

\section{Data Analysis}

Water-quality, streamflow, well-discharge, and streambed-sediment data are summarized in tables in this report. The data are grouped to represent conditions before, during, and after well discharge, and comparisons of selected data are made between those periods. Loading of arsenic to the river system as well as estimates of evapotranspiration/ seepage loss of well water were done as a preliminary quantification of the hydrologic and geochemical properties of this system before, during, and after the well-discharge period. In addition to summary tables of data, ranges of trace-element concentrations measured in streambed-sediment samples are shown in boxplots. Time-series graphs are shown for concentrations, loads (concentration multiplied by streamflow), and yields (load divided by drainage area) of selected constituents. Drainage areas for each surfacewater station were determined using U.S. Geological Survey (2012c). Graphs of associations of selected constituents are shown with regression analysis. The nonparametric two-sided Wilcoxon rank-sum test (Wilcoxon, 1945) was used to compare locations of distributions of trace-element concentrations in paired groups of streambed-sediment samples. The TIBCO Spotfire S-plus 8.1 program (TIBCO Software, 2008) was used to compute data summaries and comparative tests and to create graphs for this report. A coefficient of determination describes the fraction of variance explained by a regression between variables (Helsel and Hirsch, 1992). The p-value of statistical tests denotes the probablility of obtaining the computed test statistic when the null hypothesis (expected result) of a statistical test is true (Helsel and Hirsch, 1995).

\section{Well Construction and Discharge}

The six wells discharged for this pilot study were more than 600 feet (ft) deep, had perforated-casing zones ranging from 295-478 ft long, had diameters from 10.00-10.75 inches, and are believed to have been drilled in the 1940s and 1950s (table 3). With the exceptions of city wells 16 and 18, pumping rates generally decreased from the start of discharge on May 7 to the cessation of well discharge on May 18, 2012 (fig. 3, table 4). Those decreases in pumping rates may have been caused by reduction in available water in the aquifer with increasing drawdown. Given that the sum of mean discharge of the six wells was $1,169 \mathrm{gal} / \mathrm{min}\left(2.60 \mathrm{ft}^{3} / \mathrm{s}\right)$ (table 5), and base flow at the upstream streamflow-gaging station on the Little River increased by about $1.70 \mathrm{ft}^{3} / \mathrm{s}$ during the well-discharge period (fig. 4), about 35 percent of the water discharged from the wells seeped into soils or was evapotranspired prior to reaching the Little River at that upstream station. Discharging the six city wells continuously for a year, assuming a loss of 35 percent before reaching the Little River, would produce an additional flow into the lake of about 400 million gallons, representing 13.6 percent of the 2.96 billion gallons of water withdrawn from the lake every year or 1.76 percent of the 22.9 billion gallons of water in storage at the conservation pool elevation of the lake of $1,039 \mathrm{ft}$ (U.S. Army Corps of Engineers, 2012). 
Table 3. Selected characteristics of city wells discharged to the Little River in Norman, Oklahoma, May 7-18, 2012.

[USGS, U.S. Geological Survey; --, unknown; (Chris Mattingly, City of Norman, written commun., 2013)]

\begin{tabular}{ccccc}
\hline $\begin{array}{c}\text { USGS and City of } \\
\text { Norman well numbers }\end{array}$ & $\begin{array}{c}\text { Well depth } \\
\text { (feet below land surface) }\end{array}$ & $\begin{array}{c}\text { Depth to first } \\
\text { casing perforation } \\
\text { (feet below land surface) }\end{array}$ & $\begin{array}{c}\text { Well } \\
\text { casing diameter } \\
\text { (inches) }\end{array}$ & Date drilled \\
\hline 351538097283401 , Well 11 & 635 & 312 & 10.75 & November 11, 1944 \\
351559097283601 , Well 12 & 671 & 376 & 10.00 & December 1944 \\
351550097283801 , Well 13 & -- & -- & -- & -- \\
351648097285101 , Well 15 & 674 & 220 & 10.75 & May 1953 \\
351643097285601 , Well 16 & 679 & 291 & 10.75 & June 1, 1953 \\
351726097290901 , Well 18 & 698 & 220 & 10.00 & -- \\
\hline
\end{tabular}

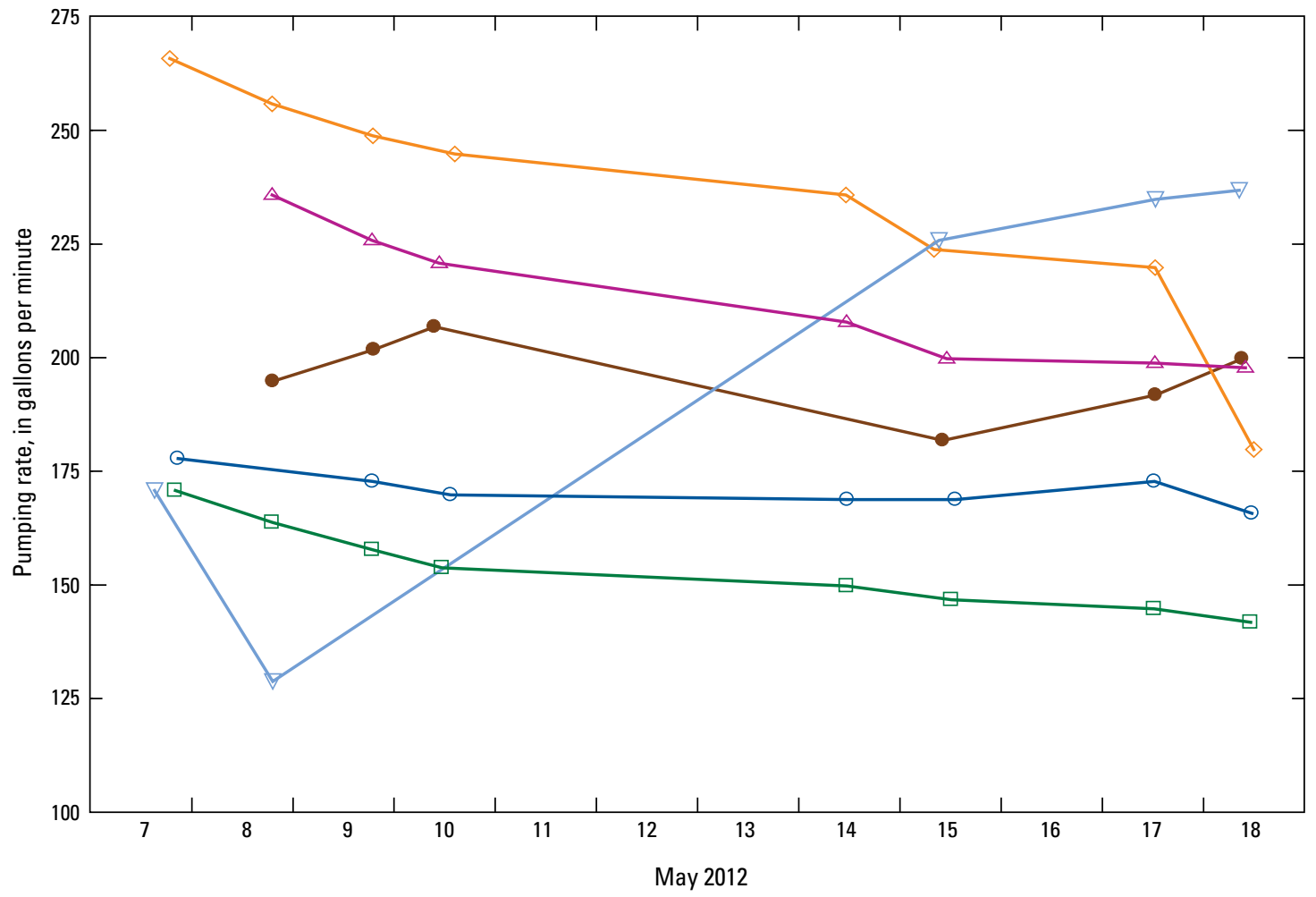

EXPLANATION

○- City well 11

$\triangle$ City well 12

$\square$ City well 13

$\curvearrowright$ City well 15

$\nabla$ City well 16

$\rightarrow-$ City well 18

Figure 3. Pumping rates for six city wells, Norman, Oklahoma, May 7-18, 2012. 
Table 4. Initial and final amount of discharge and percentage change in discharge rate for the six city wells in Norman, Oklahoma, May 7-18, 2012.

[USGS, U.S. Geological Survey; gal/min, gallons per minute]

\begin{tabular}{lccc}
\hline $\begin{array}{c}\text { USGS and City } \\
\text { Norman well numbers }\end{array}$ & $\begin{array}{c}\text { Initial } \\
\text { discharge } \\
\text { rate } \\
\text { (gal/min) }\end{array}$ & $\begin{array}{c}\text { Final } \\
\text { discharge } \\
\text { rate } \\
\text { (gal/min) }\end{array}$ & $\begin{array}{c}\text { Change in } \\
\text { discharge } \\
\text { rate } \\
\text { (percent) }\end{array}$ \\
\hline 351538097283401 , Well 11 & 178 & 166 & -6.74 \\
351559097283601 , Well 12 & 236 & 198 & -16.1 \\
351550097283801 , Well 13 & 171 & 142 & -17.0 \\
351648097285101, Well 15 & 266 & 180 & -32.3 \\
351643097285601 , Well 16 & 171 & 237 & 38.6 \\
351726097290901, Well 18 & 195 & 200 & 2.56 \\
Mean & $\mathbf{2 0 3}$ & $\mathbf{1 8 7}$ & $\mathbf{- 7 . 8 8}$ \\
\hline
\end{tabular}

Table 5. Mean discharges of the six city wells in Norman, Oklahoma, May 7-18, 2012.

[USGS, U.S. Geological Survey; gal/min, gallons per minute; $\mathrm{ft}^{3} / \mathrm{s}$, cubic feet per second; L/d, liters per day]

\begin{tabular}{cccr}
\hline \multirow{2}{*}{$\begin{array}{c}\text { USGS and City of } \\
\text { Norman well numbers }\end{array}$} & \multicolumn{3}{c}{$\begin{array}{c}\text { Mean well- } \\
\text { water discharge }\end{array}$} \\
\cline { 2 - 4 } & (gal/min) & (ft $\mathbf{3} / \mathbf{s})$ & (L/d) \\
\hline 351538097283401 , Well 11 & 171 & 0.381 & 933,000 \\
351559097283601 , Well 12 & 213 & 0.474 & $1,160,000$ \\
351550097283801 , Well 13 & 154 & 0.343 & 839,000 \\
351648097285101, Well 15 & 235 & 0.523 & $1,280,000$ \\
351643097285601, Well 16 & 200 & 0.445 & $1,090,000$ \\
351726097290901, Well 18 & 196 & 0.437 & $1,070,000$ \\
$\begin{array}{c}\text { Sum of mean well-water } \\
\text { discharge }\end{array}$ & $\mathbf{1 , 1 6 9}$ & $\mathbf{2 . 6 0}$ & $\mathbf{6 , 3 7 2 , 0 0 0}$ \\
\hline
\end{tabular}

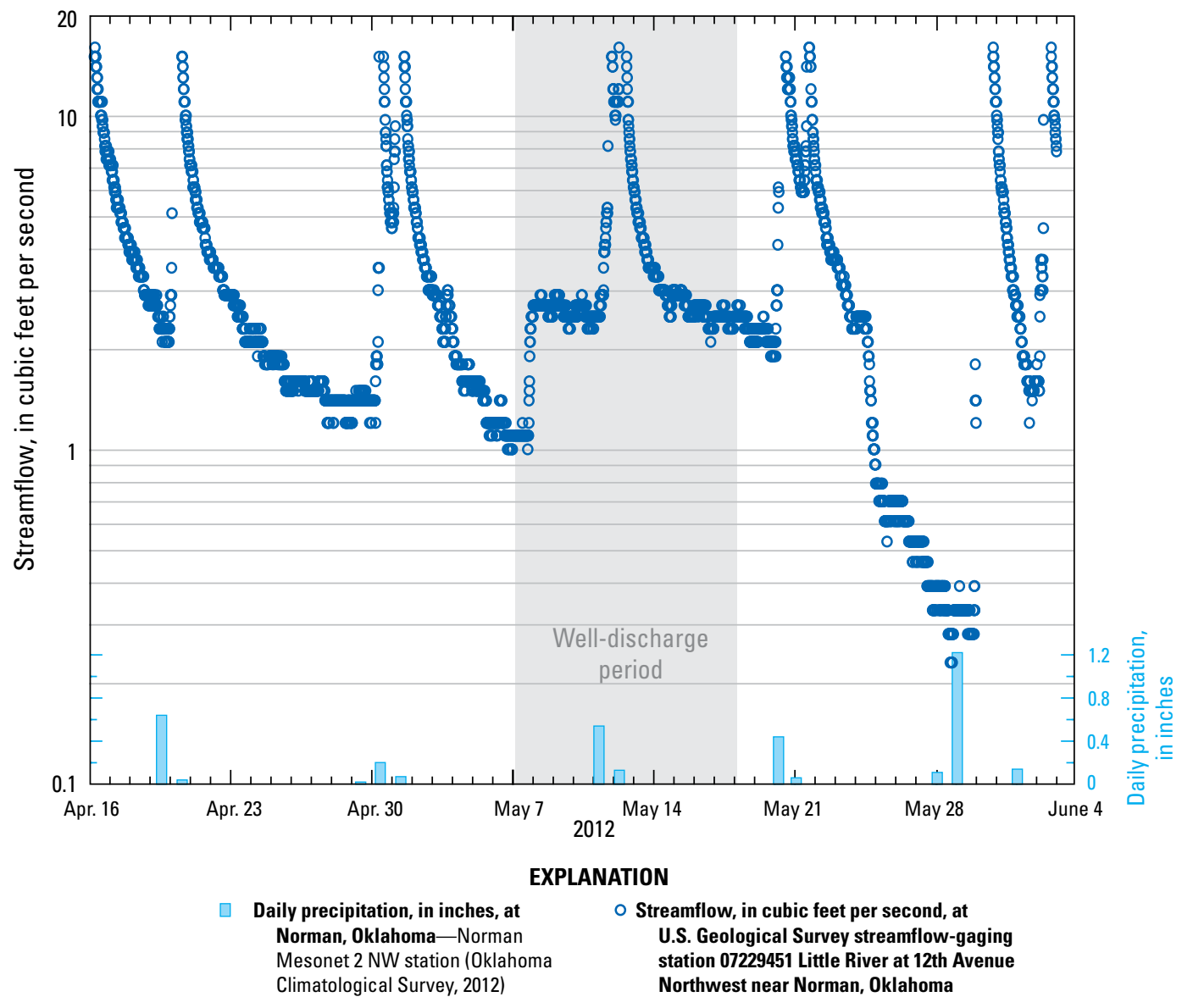

Figure 4. Streamflow measured at a streamflow-gaging station and daily precipitation in or near Norman, Oklahoma, April-June 2012. 


\section{Streamflow}

Streamflow measured at the upstream streamflowgaging station (Little River at 12th Avenue Northwest) from April-June 2012, varied from less than 1 to nearly $20 \mathrm{ft}^{3} / \mathrm{s}$, with streamflow peaks coinciding with six rainfall events having amounts ranging from less than 0.2 inch to nearly 1.5 inches (fig. 4). Continuous streamflow was available from the farthest rated upstream streamflow-gaging station whereas synoptic streamflow measurements (measured at the time of water-quality sampling) were available at the other three streamflow-gaging stations (table 6). Despite different amounts of rainfall among those precipitation events, streamflow peaks coinciding with rainfall consistently reached about $15 \mathrm{ft}^{3} / \mathrm{s}$ at the Little River at 12th Avenue Northwest streamflow-gaging station following each of those events (fig. 4). Base flow generally decreased during the April to June period of this study, though base flow increased from about $1.0 \mathrm{ft}^{3} / \mathrm{s}$ before wells discharged to the river to about $2.7 \mathrm{ft}^{3} / \mathrm{s}$ during well discharge (fig. 4), with the well discharge increasing streamflow at that station by about $1.7 \mathrm{ft}^{3} / \mathrm{s}$ during the discharge period.
Streamflow-transport times were calculated from the farthest upstream streamflow-gaging station (Little River at 12th Avenue Northwest) to the farthest downstream streamflow-gaging station (Little River near Franklin). The distance between the farthest upstream and downstream gages was divided into 34 intervals of about 1,640 ft (500 meters; appendix 2). Intervals at $0,16,400,32,800$, and $55,800 \mathrm{ft}$ were the distances of downstream surface-water sampling sites (Little River at 12th Avenue Northeast, at 36th Avenue Northeast, and near Franklin, respectively) from the upstream site. Measured instantaneous stream velocities (table 7) were used to calculate 2-point and 3-point moving-average stream velocities (table 8) that were applied when estimating watertransport times for each 1,640-ft stream increment between the farthest upstream and downstream streamflow-gaging station (appendix 2). Two-point average calculations were done only for the farthest upstream (12th Avenue Northwest) and downstream (Little River Near Franklin) sampling sites, whereas 3-point average calculations were done for sampling sites in between the farthest upstream and downstream sites (12th Avenue Northeast and 36th Avenue Northeast).

Table 6. Selected characteristics of surface-water sites sampled in or near Norman, Oklahoma, April-June 2012.

[USGS, U.S. Geological Survey]

\begin{tabular}{clcc}
\hline $\begin{array}{c}\text { USGS site } \\
\text { number }\end{array}$ & \multicolumn{1}{c}{ Site name and gaging status } & $\begin{array}{c}\text { Latitude and } \\
\text { longitude }\end{array}$ & $\begin{array}{c}\text { Upstream } \\
\text { contributing area } \\
\text { (decimal degrees) }^{\text {1,2 }}\end{array}$ \\
\hline 07229451 & Little River at 12th Avenue Northwest near Norman, Okla. (gaged, streamflow rated) & $35.268 \mathrm{~N}, 97.459 \mathrm{~W}$ \\
07229456 & Little River at 12th Avenue Northeast near Norman, Okla. (ungaged) & $35.274 \mathrm{~N}, 97.424 \mathrm{~W}$ \\
07229463 & Little River at 36th Avenue Northeast near Norman, Okla. (ungaged) & $35.279 \mathrm{~N}, 97.388 \mathrm{~W}$ & 41.3 \\
07229480 & Little River near Franklin, Okla. (gaged, streamflow unrated) & $35.276 \mathrm{~N}, 97.340 \mathrm{~W}$ & 88.8
\end{tabular}

${ }^{1}$ U.S. Geological Survey $(2012 b, c)$.

${ }^{2}$ Latitude and longitude were computed using the North American Datum of 1983.

Table 7. Instantaneous stream velocities by date, time, and location for surface-water-sampling sites in or near Norman, 0klahoma, May 8-22, 2012.

[Stream velocities, in feet per hour]

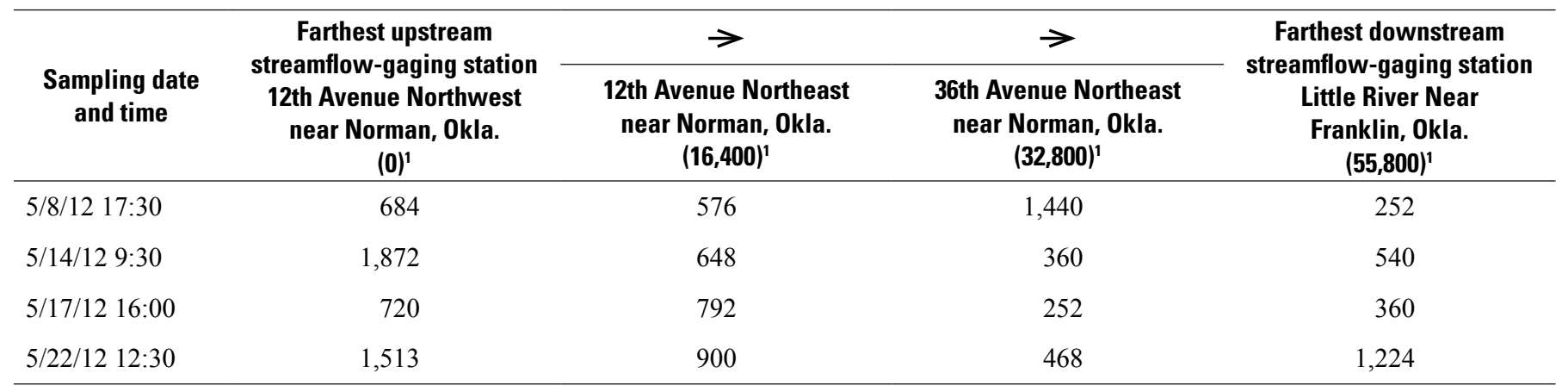

${ }^{1}$ Values in parenthesis refer to distance in feet from the upstream streamflow-gaging station. 
Table 8. Stream-interval lengths and 2-point or 3-point movingaverage stream velocities in each interval used to calculate arrival times for surface-water sampling dates of the Little River in or near Norman, Oklahoma, May 8-22, 2012.

[Units are in feet per hour, bold font signifies 2-point moving average of stream velocity, regular font signifies 3-point moving-average of stream velocity]

\begin{tabular}{ccccc}
\hline $\begin{array}{c}\text { Stream interval, } \\
\text { in distance from } \\
\text { input of well } \\
\text { discharge } \\
\text { (feet) }\end{array}$ & \multicolumn{4}{c}{ Surface-water sampling dates } \\
\cline { 2 - 5 } & $\mathbf{5 / 8 / 2 0 1 2}$ & $\mathbf{5 / 1 4 / 2 0 1 2}$ & $\mathbf{5 / 1 7 / 2 0 1 2}$ & $\mathbf{5 / 2 2 / 2 0 1 2}$ \\
\hline 0 to 8,200 & $\mathbf{6 3 0}$ & $\mathbf{1 , 2 6 0}$ & $\mathbf{7 5 6}$ & $\mathbf{1 , 2 1 0}$ \\
9,840 to 24,600 & 900 & 960 & 588 & 960 \\
26,200 to 44,300 & 756 & 516 & 468 & 864 \\
45,900 to 55,800 & $\mathbf{8 4 6}$ & $\mathbf{4 5 0}$ & $\mathbf{3 0 6}$ & $\mathbf{8 4 6}$ \\
\hline
\end{tabular}

\section{Attenuation of Arsenic and Selected Trace Elements}

\section{Well-Water Quality}

Four water samples collected from each of the wells in May, 2012, contained a median dissolved arsenic concentration of $42.1 \mu \mathrm{g} / \mathrm{L}$. All of the well-water samples contained dissolved arsenic concentration greater than the primary drinking-water standard of $10 \mu \mathrm{g} / \mathrm{L}$ (fig. 5, table 9). Concentrations of the other analyzed trace elements were less than primary or secondary drinking-water standards (aluminum, 50 to $200 \mu \mathrm{g} / \mathrm{L}$; barium, 2,000 $\mu \mathrm{g} / \mathrm{L}$; chromium, $100 \mu \mathrm{g} / \mathrm{L}$; manganese, $50 \mathrm{mg} / \mathrm{L}$; and selenium, $50 \mu \mathrm{g} / \mathrm{L}$; U.S. Environmental Protection Agency, 2012; table 9). Concentrations of aluminum, arsenic, barium, chromium, manganese, selenium, and vanadium varied during the well-discharge period (fig. 5). Some of the most substantial changes in trace-element concentrations during the welldischarge period were increases of about $7 \mu \mathrm{g} / \mathrm{L}$ in aluminum concentration in water from city well 11 , and increases of more than $100 \mu \mathrm{g} / \mathrm{L}$ of barium and about $10 \mu \mathrm{g} / \mathrm{L}$ of chromium in water from city well 13, decrease of manganese concentration of about $2 \mathrm{mg} / \mathrm{L}$ with subsequent increase of about $1 \mathrm{mg} / \mathrm{L}$ in water from city well 12 , and increase in manganese concentration of about $2 \mathrm{mg} / \mathrm{L}$ in water from city well 16 (fig. 5). Arsenic concentration generally decreased slightly in water discharged from most of the city wells during the discharge period (fig. 5), which may have been caused by gradual flushing of more readily soluble arsenic on aquiferparticle rims in the COA surrounding the wells. Similar to results described in Schlottmann and others (1998), well water with larger (more alkaline) values of $\mathrm{pH}$ contained greater arsenic concentrations, as shown in some samples from wells with $\mathrm{pH}$ measured and arsenic concentration determined (fig. 6).

Concentrations of arsenic compounds, including arsenite, arsenate, monomethylarsonate, and dimethylarsinate, were analyzed in well-water samples collected on May 18, 2012, from each of the six city wells. Arsenate was the only form of detectable arsenic in those six well-water samples (table 10).

With mean discharges from the six city wells ranging from 0.343 to $0.523 \mathrm{ft}^{3} / \mathrm{s}$ (table 5), the total load of arsenic in pumped well water decreased from 0.314 kilograms per day (kg/d) on May 7, 2012, to $0.255 \mathrm{~kg} / \mathrm{d}$ on May 18, 2012. Those decreases coincided with decreases in well-water discharges and arsenic concentrations (figs. 3, 5, and 7).

\section{Surface-Water Quality}

The dissolved arsenic concentration of water samples collected in the Little River increased at the four sampled surface-water sites after discharge of wells to the Little River began on May 7 (fig. 8). The greatest increase in arsenic concentration was measured at the streamflow-gaging station nearest to the discharging wells (Little River at 12th Avenue Northwest) with the arsenic concentrations in surface water being less than the arsenic concentrations in the pumped well water from most of the wells (figs. 5 and 8). As the water flowed downstream, the dissolved arsenic concentration decreased by 50 percent or more in the river with none of the downstream water samples having arsenic concentrations exceeding the primary drinking-water standard of $10 \mu \mathrm{g} / \mathrm{L}$ (fig. 8). In addition, the concentrations of arsenic in wellwater and surface-water samples collected for the study did not exceed the National Recommended Water Quality Criteria of $340 \mu \mathrm{g} / \mathrm{L}$ (Criteria Maximum Concentration) or $150 \mu \mathrm{g} / \mathrm{L}$ (Criteria Continuous Concentration) set to protect aquatic life (U.S. Environmental Protection Agency, 2006). Eisler (1988), in a review of arsenic toxicity data, concluded that a freshwater quality criteria of $40 \mu \mathrm{g} / \mathrm{L}$ would be more protective of most forms of aquatic life. The largest arsenic concentration measured in surface water was less than $30 \mu \mathrm{g} / \mathrm{L}$, indicating that no known toxic risk to aquatic biota would be expected from these well discharges according to Eisler (1988) and U.S. Environmental Protection Agency (2006) (fig. 8). 

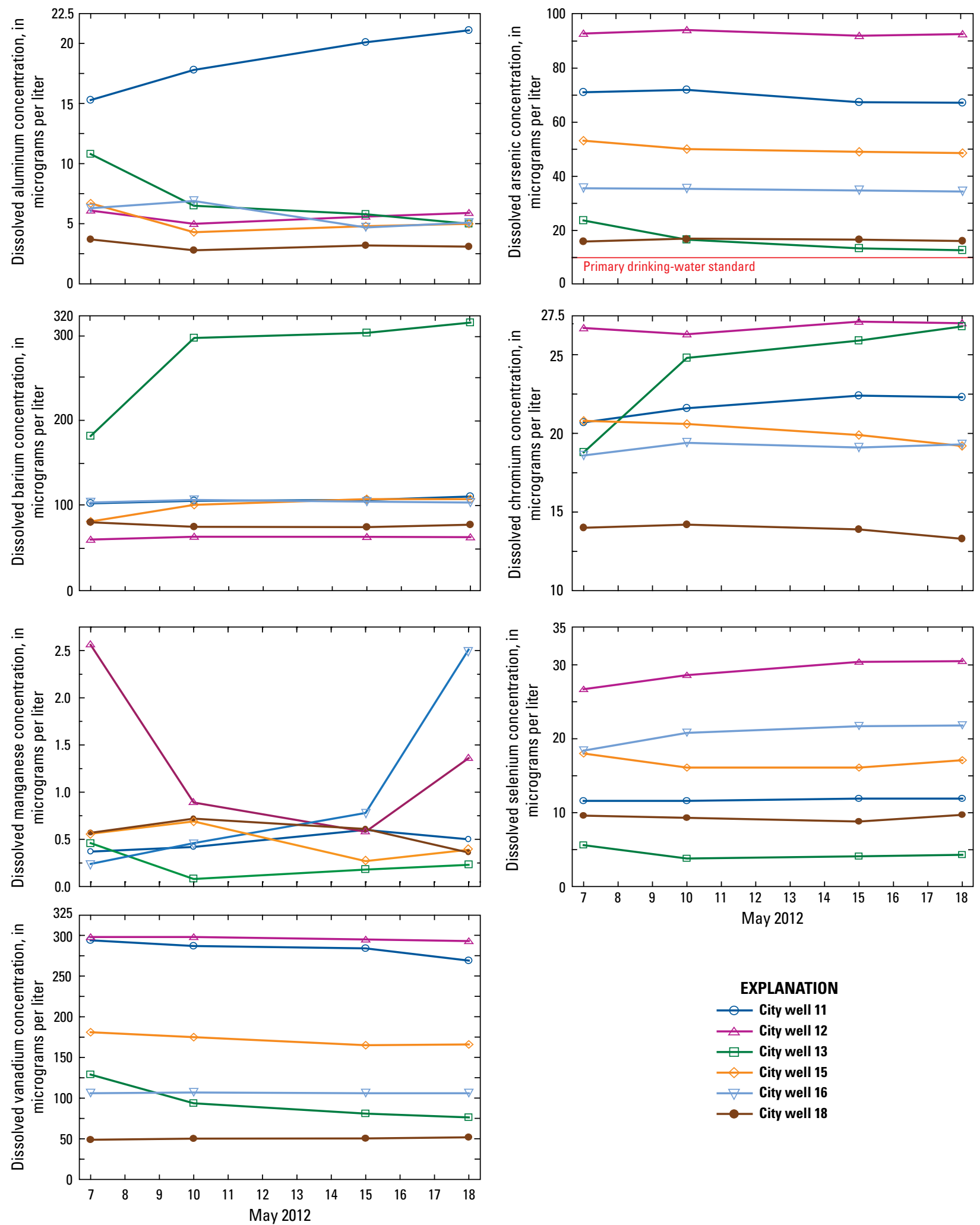

Figure 5. Concentrations of selected trace elements with time discharged at six city wells in Norman, Oklahoma, May 7-18, 2012. 
Table 9. Summary statistics of dissolved concentrations of selected trace elements in 24 samples of water discharged by six city wells in Norman, Oklahoma, May 7-18, 2012.

$[\mu \mathrm{g} / \mathrm{L}$, micrograms per liter; $<$, less than]

\begin{tabular}{lcccc}
\hline Trace element & Range of data & $\begin{array}{c}\text { Percentage of } \\
\text { nondetectable data } \\
\text { of } \mathbf{2 4} \text { samples }\end{array}$ & $\begin{array}{c}\text { Mean } \\
\text { concentration } \\
(\boldsymbol{\mu g} / \mathbf{L})\end{array}$ & $\begin{array}{c}\text { Median } \\
\text { concentration } \\
(\boldsymbol{\mu g} / \mathbf{L})\end{array}$ \\
\hline Aluminum & $2.80-21.1$ & 0.00 & 7.57 & 5.70 \\
Arsenic & $12.7-94.1$ & 0.00 & 46.8 & 42.1 \\
Barium & $58.6-313$ & 0.00 & 119 & 102 \\
Chromium & $13.3-27.1$ & 0.00 & 20.9 & 20.6 \\
Iron & $<3.20-8.80$ & 45.8 & 3.38 & 3.25 \\
Manganese & $<0.160-2.56$ & 4.17 & 0.683 & 0.530 \\
Selenium & $3.80-30.5$ & 0.00 & 15.4 & 14.0 \\
Vanadium & $48.8-298$ & 0.00 & 167 & 147 \\
\hline
\end{tabular}

${ }^{1}$ Nondetectable data converted to one-half of reporting limit to compute mean value.

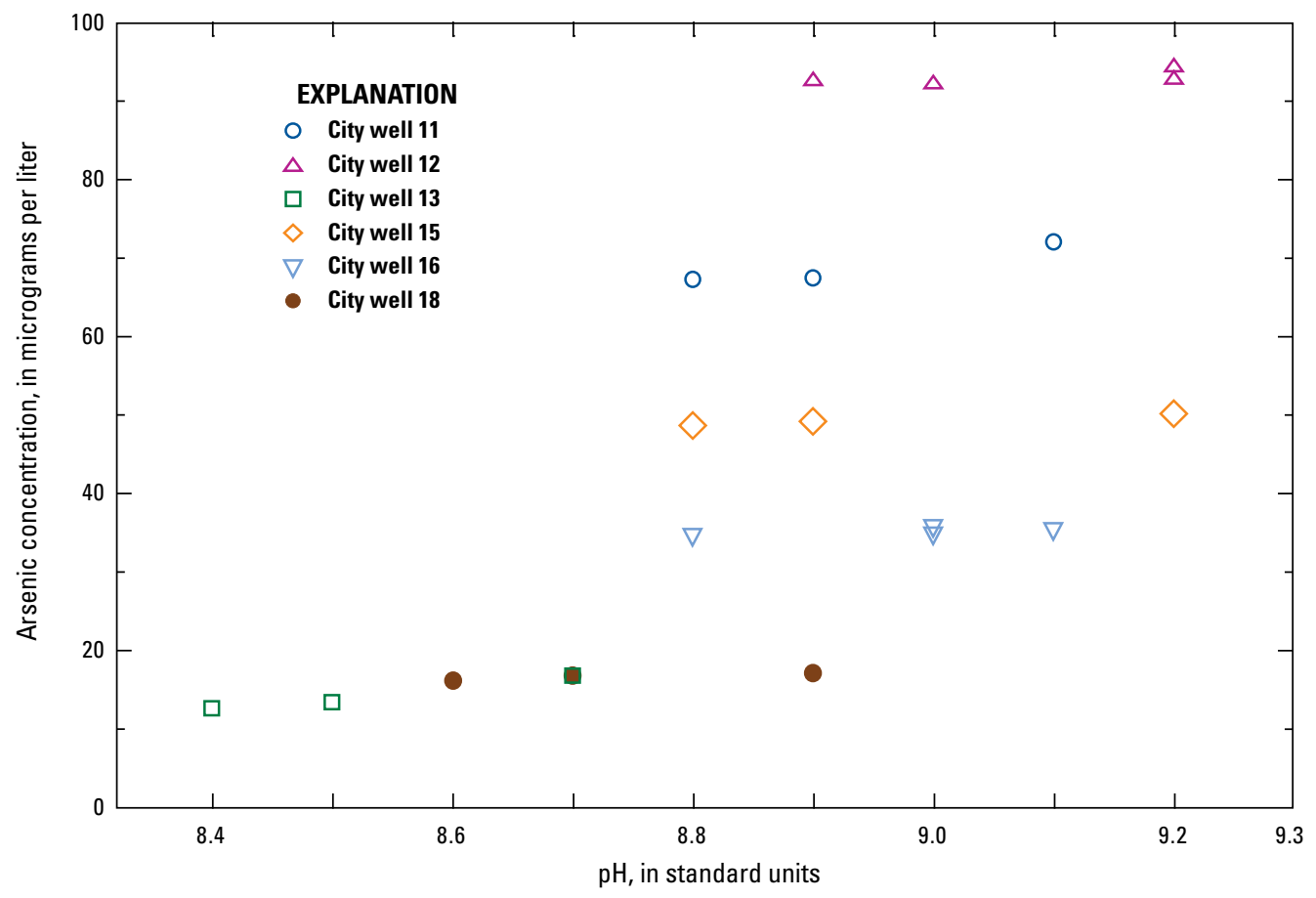

Figure 6. Arsenic concentration and pH values in water samples collected from six city wells in Norman, Oklahoma, May 7-18, 2012. 
Table 10. Dissolved concentrations of selected arsenic types in water samples collected from six city wells in Norman, Oklahoma, May 18, 2012.

[USGS, U.S. Geological Survey; all concentrations in micrograms per liter; $<$, less than]

\begin{tabular}{ccccc}
\hline $\begin{array}{c}\text { USGS and City of } \\
\text { Norman well numbers }\end{array}$ & Arsenite & Arsenate & Monomethylarsonate & Dimethylarsinate \\
\hline 351538097283401 , Well 11 & $<2.00$ & 56.0 & $<16.0$ & $<3.00$ \\
351559097283601 , Well 12 & $<2.00$ & 93.5 & $<16.0$ & $<3.00$ \\
351550097283801 , Well 13 & $<0.40$ & 12.5 & $<3.20$ & $<0.60$ \\
351648097285101 , Well 15 & $<0.40$ & 38.2 & $<3.20$ & $<0.60$ \\
351643097285601 , Well 16 & $<0.40$ & 28.7 & $<3.20$ & $<0.60$ \\
351726097290901 , Well 18 & $<0.40$ & 13.8 & $<3.20$ & $<0.60$ \\
\hline
\end{tabular}

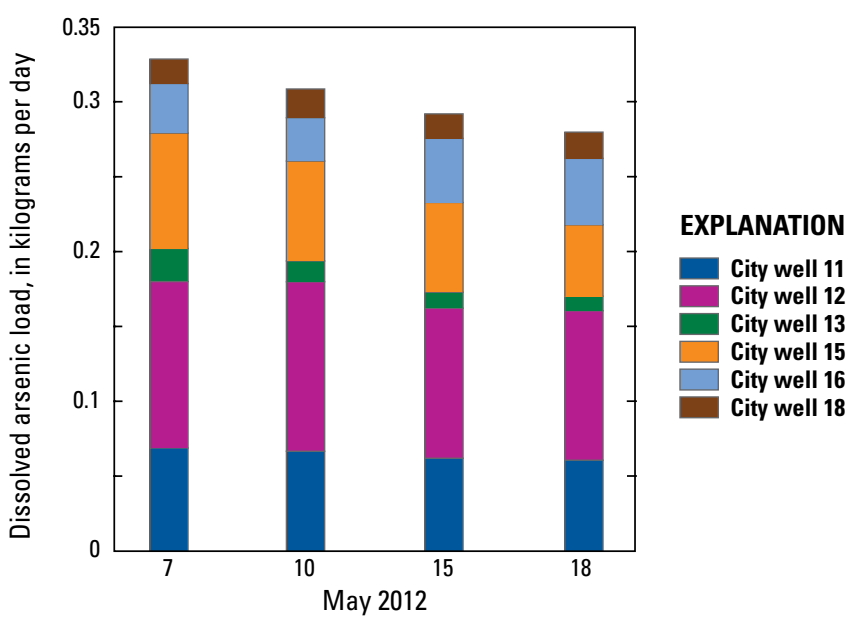

Figure 7. Dissolved arsenic loads produced by six city wells in Norman, Oklahoma, May 7-18, 2012.

Decreased arsenic concentration downstream from the area of well-water discharge to the river likely was caused by a combination of natural-attenuation processes. These processes include dilution from water added to the river by base-flow seepage along the streambank and inflows from tributaries, sorption of dissolved arsenic to mineral surfaces, and seepage of surface water into the hyporheic zone in streambed and streambank sediments. Arsenic concentration in water in the river generally decreased after the discharge of well water ceased. An exception was the farthest downstream station (Little River near Franklin, Okla.), where arsenic concentration in the river continued to increase for 10 days after the well-water discharge ceased (fig. 8). The later peak of arsenic concentration may have been caused by: (1) additional time needed for water to flow downstream, (2) outseepage of high-arsenic river water that had seeped into the hyporheic zone, and (3) desorption of arsenic from mineral phases that equilibrated with higher-arsenic river water during the wellwater discharge with subsequent release of arsenic to lowerarsenic river water after discharge. Arsenic concentration in the Little River returned to near background (conditions prior to well-water discharge) at the farthest upstream and downstream surface-water sampling sites by June 1, 2012, 14 days after the well-water discharges to the river had ceased (fig. 8). Although arsenic concentrations decreased in the downstream direction, increasing streamflow at downstream stations tended to make arsenic loads relatively similar at the three downstream stations during and immediately following the well-discharge period (fig. 8).

Discharge of arsenic from the wells and the smaller upstream basin area of the farthest upstream station (Little River at 12th Avenue Northwest) caused the yield of arsenic to be considerably larger at that station than for the downstream stations (fig. 8). Arsenic yields decreased more than 50 percent in the downstream direction.

Precipitation falling during the sampling period also affected transport of arsenic in the river (fig. 8). The rainfall event of about 1-2 inches near the end of May, in particular, may have caused the increases in arsenic loads and yields in the Little River by increasing overland flow, inflows from tributaries, and resuspension of arsenic in streambed sediments (figs. 4 and 8). 

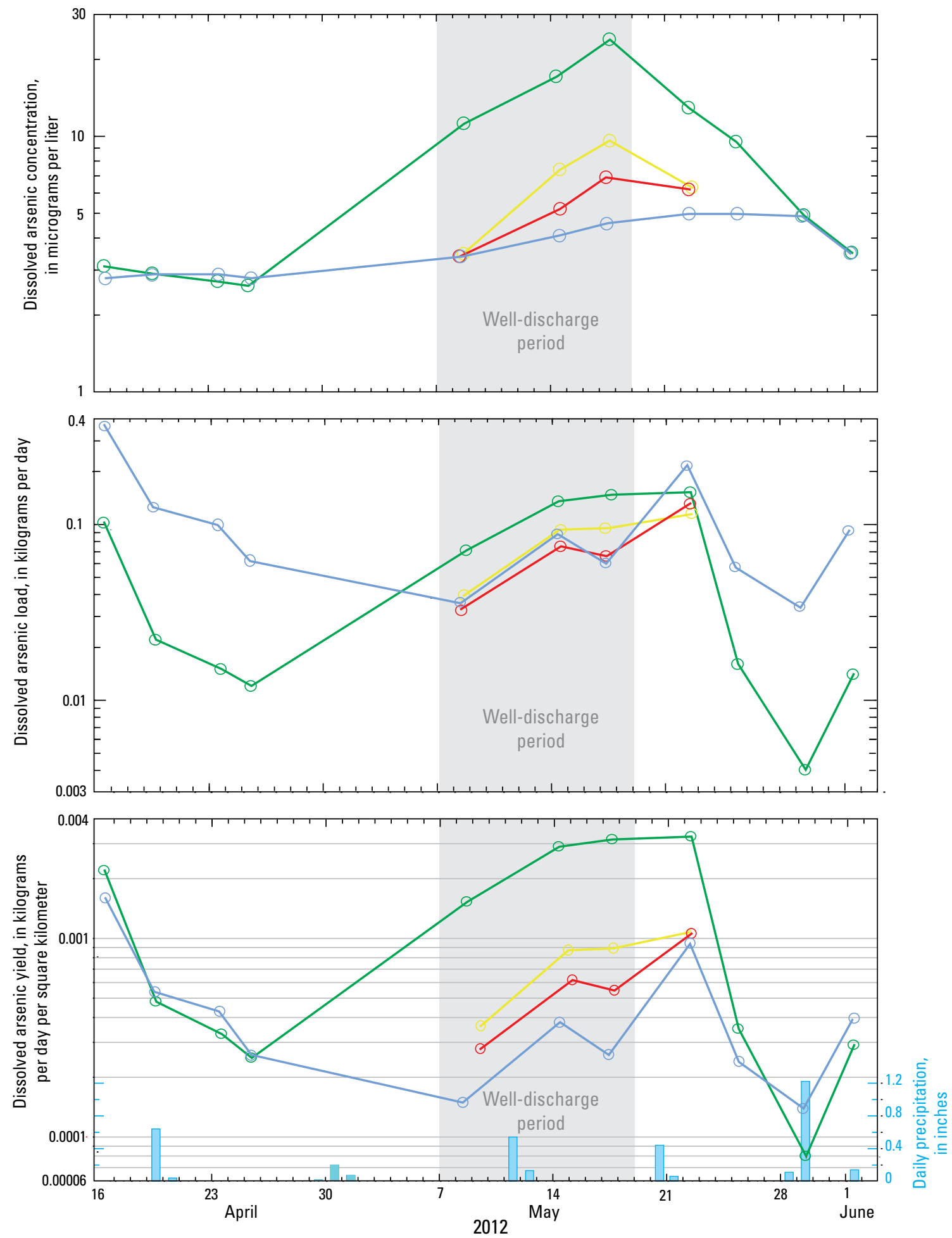

EXPLANATION

$\square$ Daily precipitation, in inches, at Norman, Oklahoma-Norman Mesonet 2 NW station (Oklahoma Climatological Survey, 2012)

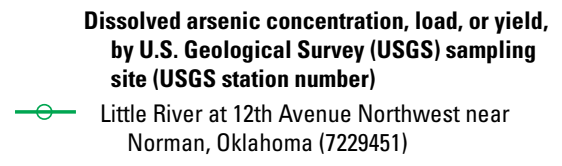

Dissolved arsenic concentration, load, or yield,
by U.S. Geological Survey (USGS) sampling site (USGS station number)

Norman, Oklahoma (7229451)

Little River at 12th Avenue Northeast near Norman, Oklahoma (7229456)

- $\_$Little River at 36th Avenue Northeast near Norman, Oklahoma (07229463)

_- Little River near Franklin, Oklahoma (07229480)

Figure 8. Dissolved arsenic concentrations, loads, and yields, and daily precipitation at four sites on the Little River sampled in or near Norman, Oklahoma, April-June 2012. 
Comparing dissolved arsenic concentration to streamflow in the Little River during the study period indicated generally greater dissolved arsenic concentration during well-water discharge, and slightly greater concentrations of arsenic after well-water discharge than in the period before well-water discharge (figs. 4 and 8). Summarizing the effects of wellwater discharge to water quality in the Little River:

1. The smallest dissolved arsenic concentrations were measured before well-water discharge began;

2. The largest arsenic concentrations were measured in the river at the end of well-water discharge;

3. Arsenic concentration decreased in the downstream direction, indicating the effects of dilution, sorption, and other natural-attenuation processes; and

4. Dissolved arsenic concentration measured in the Little River gradually decreased to concentrations similar to those measured in the period before well-water discharge over a 14-day period after well-water discharge to the river ceased.

Concentrations of other measured trace elements with substantial correlations with arsenic in water samples collected from the Little River included chromium, selenium, and vanadium (fig. 9, table 11). These trace elements have chemical properties similar to those of arsenic and are expected to occur as dissolved oxyanions in the COA. Schlottmann and others (1998) described coincident increases of concentrations of arsenic, chromium, and selenium in water with depth in parts of the COA. In addition to concerns about elevated concentration of arsenic in well water, concern has been expressed about the concentration of hexavalent chromium $\left(\mathrm{Cr}^{+6}\right)$ in city drinking water (Environmental Working Group, 2010; City of Norman, 2012). Filtered (dissolved) and unfiltered (total) concentrations of chromium were analyzed in well water and surface water. Although $\mathrm{Cr}^{+6}$ concentration was not analyzed in those samples, given the oxic conditions of this aquifer, much of the chromium in water may be in the $\mathrm{Cr}^{+6}$ form.

To further investigate the decrease in arsenic concentration in the Little River through natural attenuation processes, streamflow transport times from the farthest upstream streamflow-gaging station (Little River at 12th Avenue Northwest near Norman, Okla.) to the farthest downstream streamflow-gaging station (Little River near Franklin, Okla.) were estimated from moving averages of water velocities measured at the four surface-water sites during sampling from May 8 to May 22, 2012 (fig. 10, table 8, appendix 2). Water traveltime between the two streamflowgaging stations on May 8, 2012 was approximately 2.9 days (fig. 10, table 12). On May 14 and 17, 2012, which were in the middle of the well-water-discharge period, traveltimes were somewhat greater at about 3.6 days and 4.9 days, respectively (fig. 10, table 12). Increased traveltimes may have been caused by backwater effects or pooling of water at downstream gages from rain events or the pumping of groundwater discharged into Little River. On May 22, 2012, 3 days after discharge of well water to the Little River had ceased, the water traveltime was about 2.5 days (fig. 10, table 12), similar to traveltime on May 8.

Arsenic load was estimated in approximately the same parcel of water as it flowed from the farthest upstream streamflow-gaging station to the other three downstream streamflow-gaging stations, though sampling was not specifically designed to measure the same parcels of water with flow downstream, and there is uncertainty regarding traveltime of water downstream, given limited measurement of streamflow velocities. Only 3 out of 13 downstream samples had calculated arrival times of water that could be paired within several hours of the estimated arrival times (based on moving average of flow velocities) to an upstream sample (table 12). Water sampled at the farthest upstream streamflowgaging station on May 14 at 09:30 was estimated to arrive at the farthest downstream station on May 18 at 00:45 and was paired to a sample collected on May 17 at 08:30. The arsenic load from the water sample collected at the farthest upstream station on May 14 was $0.135 \mathrm{~kg} / \mathrm{d}$, whereas the load from the paired sample at the farthest downstream station was 0.059 $\mathrm{kg} / \mathrm{d}$, a loss of $0.076 \mathrm{~kg} / \mathrm{d}$ or -56.3 percent (fig. 8). Water sampled at the farthest upstream streamflow-gaging station on May 17 at 16:00 was estimated to arrive at the farthest downstream station on May 22 at 14:00 and was paired to a sample collected at that downstream station on May 22 at 09:00. The arsenic load from the sample at the farthest upstream station on May 17 was $0.147 \mathrm{~kg} / \mathrm{d}$, whereas the load from the sample at the farthest downstream station was 0.216 $\mathrm{kg} / \mathrm{d}$, an increase of $0.069 \mathrm{~kg} / \mathrm{d}$ or 46.9 percent (fig. 8). Water sampled at the farthest upstream streamflow-gaging station on May 22 at 12:30 was estimated to arrive at the farthest downstream station on May 25 at 00:45 and was paired to a sample collected at the downstream station on May 25 at 08:00. The arsenic load of the upstream sample collected on May 22 was $0.152 \mathrm{~kg} / \mathrm{d}$, whereas the load at the downstream station was $0.056 \mathrm{~kg} / \mathrm{d}$, a decrease of $0.096 \mathrm{~kg} / \mathrm{d}$ or -63.2 percent (fig. 8). The total amount of arsenic removed from the well water as it flowed to the farthest downstream gaging station after well discharge was about $0.24 \mathrm{~kg}$ or 0.53 pound per day during base-flow conditions (figs. 7 and 8).

The increase in dissolved arsenic load in the downstream direction of the May 17 and May 22 paired samples may be related to the rainfall event of about one-half inch on May 20 and 21, 2012 (figs. 4 and 8). That rainfall, in addition to the well water discharged to the Little River, may have produced additional runoff containing arsenic (fig. 11). No rainfall was recorded during flow of the paired samples collected from May 14 through May 18, 2012, and May 22 through May 25, 2012. 

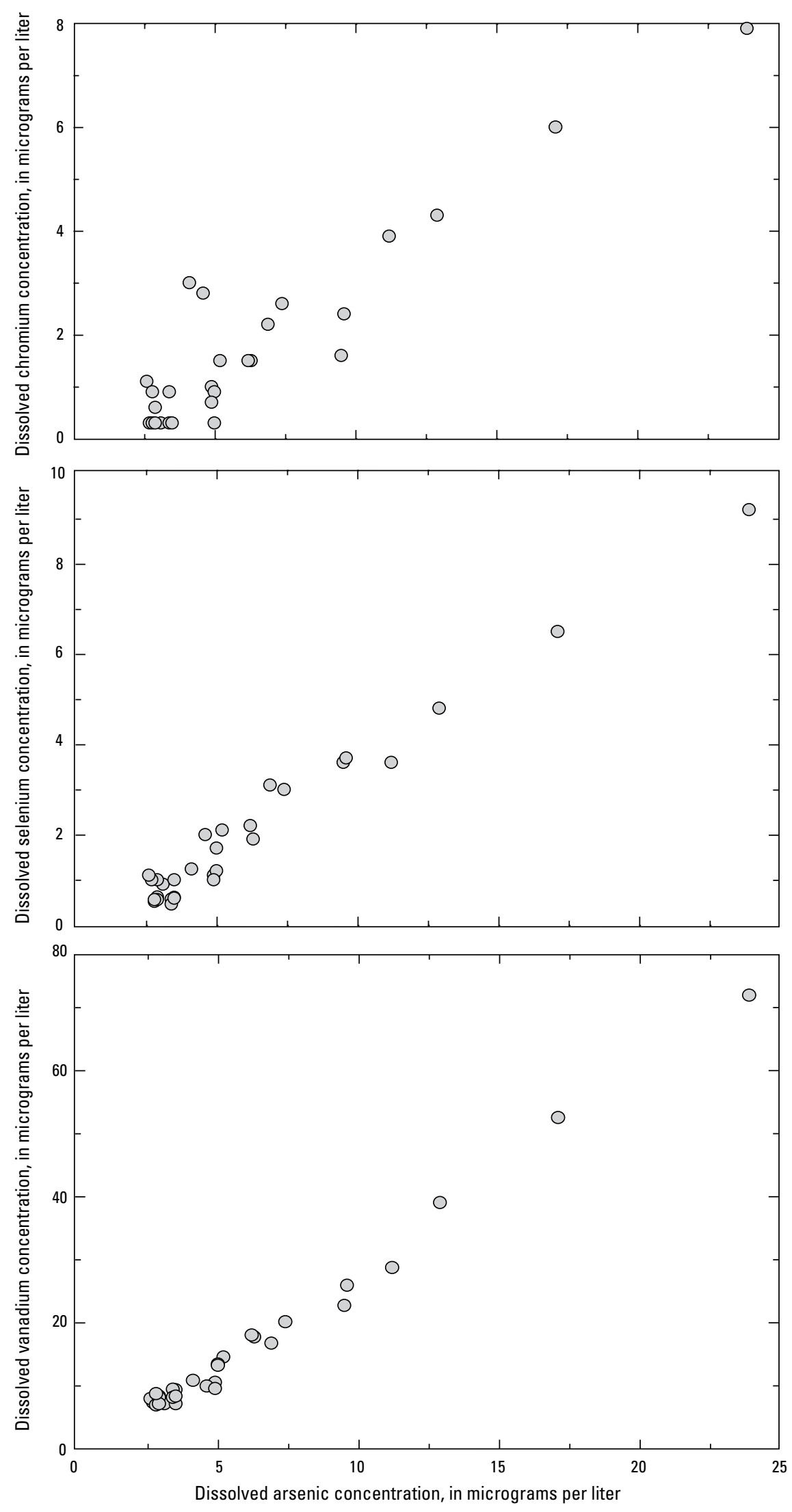

Figure 9. Dissolved arsenic concentrations with concentrations of chromium, selenium, and vanadium in surface-water samples collected at four sites on the Little River in or near Norman, Oklahoma, April-June 2012. 
Table 11. Coefficient of determination $\left(r^{2}\right)$ of linear regressions of dissolved concentrations of selected trace elements in 30 water samples collected at four sites' on the Little River in or near Norman, Oklahoma, April-June 2012.

[Values of one-half of reporting limits substituted for nondetectable values; p-value in parentheses, p-value greater than 0.05 indicates no correlation]

\begin{tabular}{|c|c|c|c|c|c|c|c|c|c|}
\hline $\begin{array}{c}\text { Trace } \\
\text { element }\end{array}$ & Aluminum & Arsenic & Barium & Chromium & Iron & Manganese & Phosphorus & Selenium & Vanadium \\
\hline Aluminum & 1.00 & & & & & & & & \\
\hline Arsenic & $\begin{array}{c}0.07 \\
(0.161)\end{array}$ & 1.00 & & & & & & & \\
\hline Barium & $\begin{array}{c}0.25 \\
(0.005)\end{array}$ & $\begin{array}{c}0.25 \\
(0.005)\end{array}$ & 1.00 & & & & & & \\
\hline Chromium & $\begin{array}{l}0.05 \\
(0.255)\end{array}$ & $\begin{array}{c}0.87 \\
(<0.001)\end{array}$ & $\begin{array}{c}0.19 \\
(0.017)\end{array}$ & 1.00 & & & & & \\
\hline Iron & $\begin{array}{c}0.50 \\
(<0.001)\end{array}$ & $\begin{array}{c}0.06 \\
(0.206)\end{array}$ & $\begin{array}{c}0.37 \\
(<0.001)\end{array}$ & $\begin{array}{l}0.04 \\
(0.267)\end{array}$ & 1.00 & & & & \\
\hline Manganese & $\begin{array}{c}0.20 \\
(0.013)\end{array}$ & $\begin{array}{l}0.04 \\
(0.270)\end{array}$ & $\begin{array}{c}0.02 \\
(0.430)\end{array}$ & $\begin{array}{c}0.04 \\
(0.284)\end{array}$ & $\begin{array}{c}0.09 \\
(0.103)\end{array}$ & 1.00 & & & \\
\hline Phosphorus & $\begin{array}{c}0.17 \\
(0.023)\end{array}$ & $\begin{array}{c}0.06 \\
(0.179)\end{array}$ & $\begin{array}{c}0.12 \\
(0.063)\end{array}$ & $\begin{array}{c}0.10 \\
(0.091)\end{array}$ & $\begin{array}{c}0.38 \\
(<0.001)\end{array}$ & $\begin{array}{c}0.04 \\
(0.271)\end{array}$ & 1.00 & & \\
\hline Selenium & $\begin{array}{c}0.05 \\
(0.216)\end{array}$ & $\begin{array}{c}0.97 \\
(<0.001)\end{array}$ & $\begin{array}{c}0.29 \\
(0.002)\end{array}$ & $\begin{array}{c}0.88 \\
(<0.001)\end{array}$ & $\begin{array}{c}0.05 \\
(0.216)\end{array}$ & $\begin{array}{c}0.04 \\
(0.315)\end{array}$ & $\begin{array}{c}0.07 \\
(0.169)\end{array}$ & 1.00 & \\
\hline Vanadium & $\begin{array}{c}0.08 \\
(0.125)\end{array}$ & $\begin{array}{c}0.99 \\
(<0.001)\end{array}$ & $\begin{array}{l}0.24 \\
(0.005)\end{array}$ & $\begin{array}{c}0.87 \\
(<0.001)\end{array}$ & $\begin{array}{c}0.06 \\
<0.183)\end{array}$ & $\begin{array}{c}0.03 \\
(0.349)\end{array}$ & $\begin{array}{c}0.05 \\
(0.236)\end{array}$ & $\begin{array}{c}0.96 \\
(<0.001)\end{array}$ & 1.00 \\
\hline
\end{tabular}

${ }^{1}$ Little River at 12th Avenue Northwest near Norman, Oklahoma, at 12th Avenue Northeast near Norman, Okla., at 36th Avenue Northeast near Norman, Okla., and near Franklin, Okla.
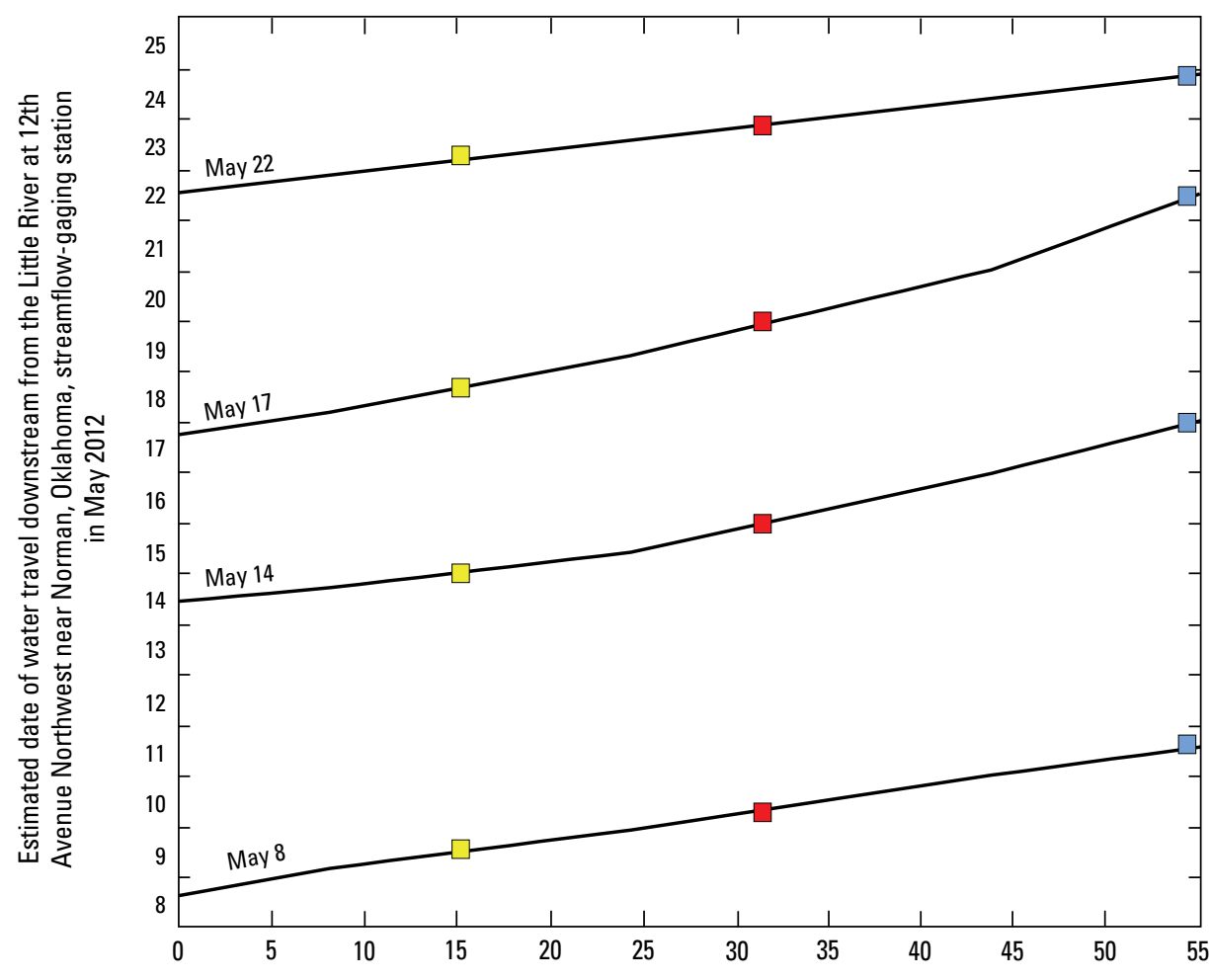

\section{EXPLANATION}

U.S. Geological Survey (USGS) streamflow-gaging station name (USGS station number)

$-\square-\quad$ Little River at 12 th Avenue Northeast near Norman Oklahoma (7229456)

Little River at 36th Avenue Northeast near Norman, Oklahoma (07229463)

Little River near Franklin, Oklahoma (07229480)

Distance downstream from the Little River at 12th Avenue Northwest near Norman, Oklahoma, streamflow-gaging station, in thousands of feet

Figure 10. Estimated traveltimes of surface water from the Little River at 12th Avenue Northwest near Norman, Oklahoma, streamflowgaging station to three downstream streamflow-gaging stations in and near Norman, Okla., May 2012. 
Table 12. Sampling dates and times shown with calculated arrival dates and traveltimes downstream and corresponding samples from the Little River at 12th Avenue Northwest near Norman, Oklahoma, streamflow-gaging station, May 2012.

[Yellow, green, and blue shades are estimated to be the same mass of water transported downstream; na, not applicable]

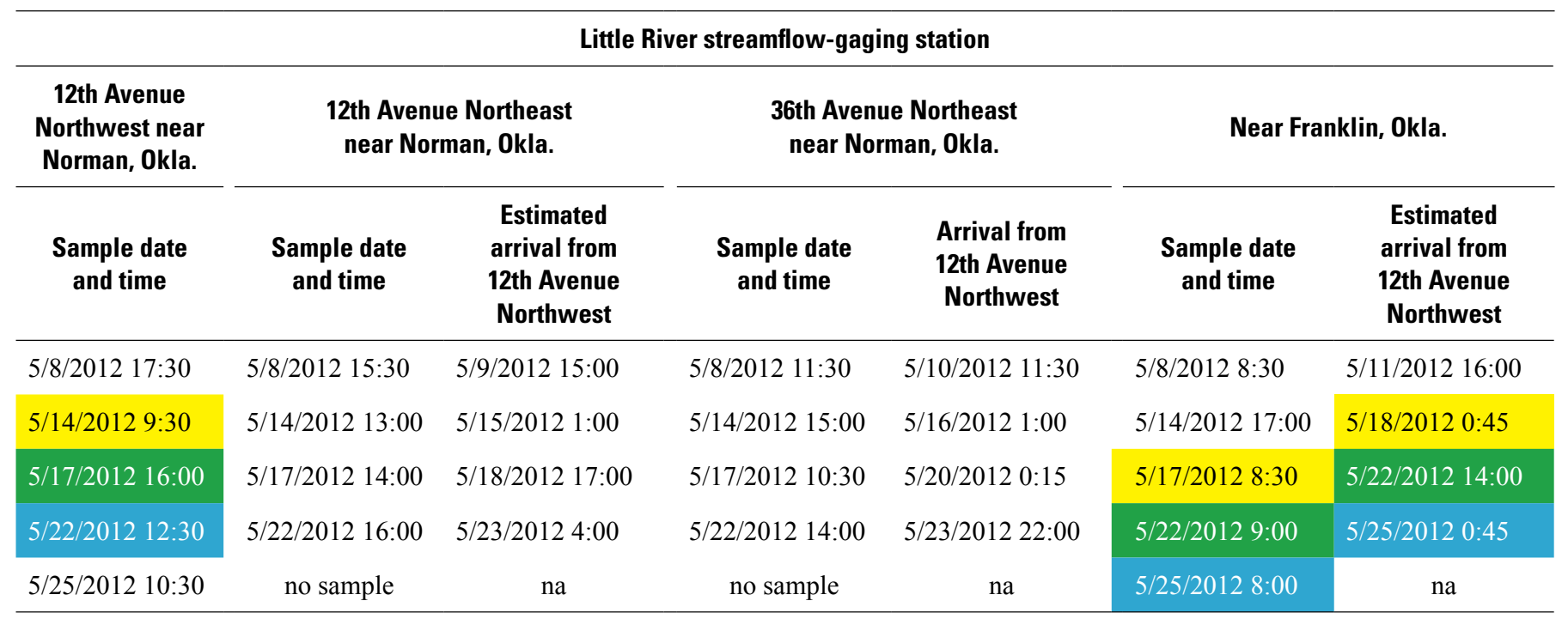

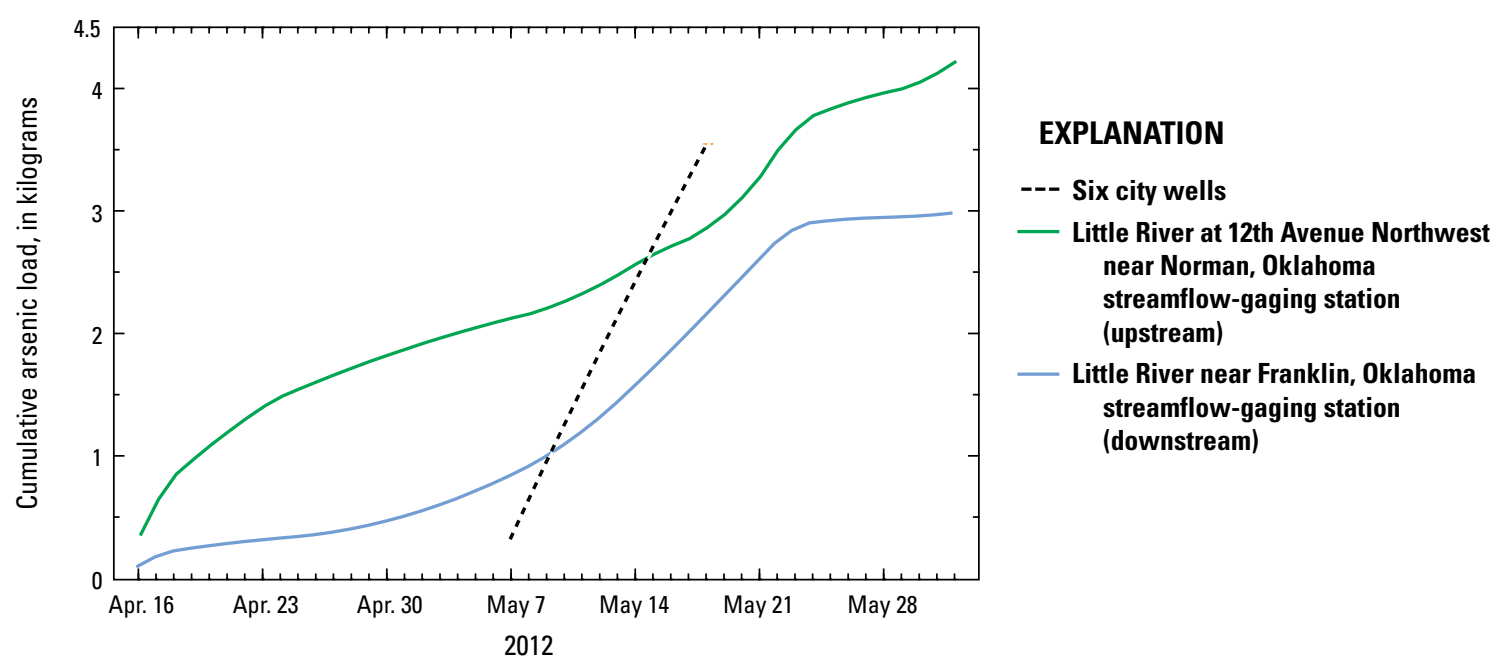

Figure 11. Estimated cumulative arsenic load discharged from six city wells and two streamflow-gaging stations on the Little River in or near Norman, Oklahoma, April 16-June 1, 2012. 
The cumulative load of dissolved arsenic added by the discharge of well water was greater than the change of cumulative dissolved arsenic load at the downstream streamflow-gaging stations during the period of well discharge (fig. 11). Cumulative arsenic loading at the upstream streamflow-gaging station, during that 12-day period was about $1 \mathrm{~kg}$, compared to $3.5 \mathrm{~kg}$ discharged at the wells (fig. 11). Allowing for about 2.5 days of lag time between well discharge and water arriving at the downstream streamflowgaging station, about $1.5 \mathrm{~kg}$ of dissolved arsenic load flowed by that station coinciding with the well-water-discharge period (fig. 11). Inflow of surface water from Elm Creek and groundwater seepage comprising base flow between these two stations may have been the source of the additional $0.5 \mathrm{~kg}$ of dissolved arsenic load flowing past the downstream station in the periods coinciding with well-water discharge.

\section{Streambed Sediments}

Concentrations of selected trace elements in streambedsediment samples collected at nine sites on the Little River did not change significantly from before well discharges began to after well discharges ceased (fig. 12, table 13). Such lack of change indicates that relatively small amounts of arsenic and other selected trace elements were sorbed to streambed sediments in the Little River during the study period. This lack of change is to be expected as ambient streambed sediment arsenic content was about 2,000 times the arsenic concentration in water, as arsenic concentration in water is expressed in micrograms per liter (or parts per billion) and arsenic concentration in sediment is expressed in milligrams per liter (or parts per million) (figs. 8 and 12). In addition, some of the streambed-sediments containing sorbed arsenic and other trace metals may have been resuspended and transported farther downstream during several rainfall events that occurred during the sampling period. Additional sampling of sediments and water flowing into the lake during a longer discharge period would be useful for developing better understanding of the fate and transport of arsenic and related trace metals in this alluvial and lacustrine system.

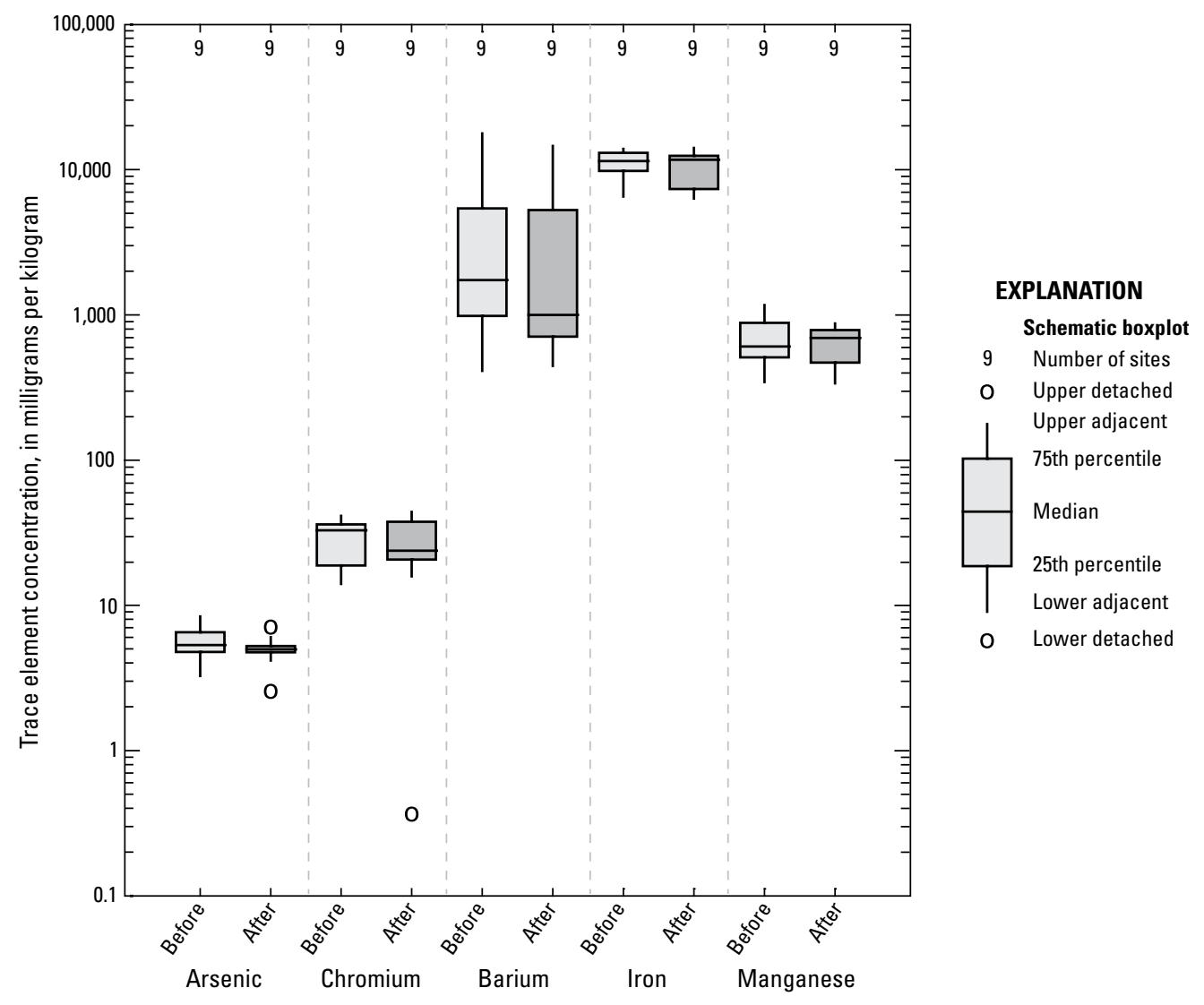

Trace element and collection time relative to well discharges

Figure 12. Distributions of selected trace-element concentrations in streambed sediments collected before and after well discharges to the Little River at nine sites in or near Norman, Oklahoma, April-June 2012. 
Table 13. Two-sided Wilcoxon rank-sum test statistics comparing the trace-element content of streambed-sediment samples collected before and after well-water discharge to the Little River, April-May 2012, at nine sites in or near Norman, Oklahoma.

[p-value greater than 0.05 indicates no significant differences in the locations of distribution of paired data sets.]

\begin{tabular}{lcc}
\hline \multicolumn{1}{c}{ Constituent } & $\begin{array}{c}\text { Rank-sum } \\
\text { test statistic }\end{array}$ & p-value \\
\hline Arsenic & 98 & 0.297 \\
Chromium & 83 & 0.546 \\
Barium & 93 & 0.863 \\
Iron & -0.3978 & 0.691 \\
Manganese & 90 & 0.730 \\
\hline
\end{tabular}

\section{Summary}

The City of Norman, Oklahoma, wanted to augment its water supplies to meet water demands of an increasing population. The city stopped using water from wells that produced water exceeding the 10 micrograms per liter primary drinking-water standard for arsenic in the mid-2000s, leaving Lake Thunderbird as the primary water supply for the city. The U.S. Geological Survey, in cooperation with the City of Norman, Okla., conducted a pilot study to investigate if discharging well water with elevated arsenic concentration into the Little River, the major tributary to Lake Thunderbird, would lower dissolved arsenic concentrations through naturalattenuation processes that may occur in the stream channel.

Pumping of about 150-250 gallons per minute from each of six city wells discharged a total of about 0.3 kilograms per day of arsenic, increased base flow at the farthest upstream streamflow-gaging station nearest to the wells by 1.7 cubic feet per second, and increased dissolved arsenic concentration in the Little River by as much as 24 micrograms per liter. Approximately two-thirds of the water discharged from the wells reached the farthest upstream streamflow-gaging station nearest to the wells, with arsenic concentrations at that station being less than the arsenic concentrations measured in many well-water samples. Arsenic concentrations, loads, and yields continued to generally decrease in the downstream direction by 50 percent or more, indicating removal of about 0.25 kilogram per day of arsenic during base-flow conditions. At the farthest upstream streamflow-gaging station, the arsenic concentration exceeded the primary drinking-water standard of 10 micrograms per liter during well discharge. At downstream streamflow-gaging stations, arsenic concentration was less than the primary drinking-water standard. All of the surface-water samples had arsenic concentrations below the thresholds expected to have adverse effects on aquatic biota.
After well-water discharges to the Little River were stopped, arsenic concentrations, loads, and yields gradually decreased over a period of about 14 days to values measured prior to the well-water discharge. Cumulative loads of arsenic discharged from the wells and the farthest upstream streamflow-gaging station indicated removal of about 2.5 kilograms of the 3.5 kilograms of discharged dissolved arsenic between the wells and the farthest upstream streamflow-gaging station at 12th Avenue Northwest. About 1.5 kilograms of dissolved arsenic flowed past the farthest downstream streamflow-gaging station near Franklin, Okla., during the period corresponding to wellwater discharge. The extra 0.5 kilogram of arsenic loading compared to the station at 12th Avenue Northwest probably was related to inflow of surface water from Elm Creek and seepage of groundwater along the stream channel between those two stations. Streambed-sediment samples collected before and after the well-water discharges did not have significant increases in arsenic concentration. Some of the streambed sediments containing sorbed arsenic may have been resuspended and transported to the lake during the increased streamflows following several rainfall events that occurred during the sampling period.

Results of this pilot study indicate that using naturalattenuation processes to remove arsenic from well water and supplement city water supplies may be a viable, relatively low-cost treatment method. Longer-term testing of this method would be needed to better evaluate potential accumulation of arsenic and other trace metals in streambed sediments and the ultimate capacity of this fluvial system for attenuating elevated arsenic concentration in pumped groundwater. Results from this study may be transferable to other areas with elevated arsenic concentrations in groundwater and combined groundwater/surface-water public-supply systems, though local conditions are likely to affect the extent of natural attenuation of arsenic.

\section{References Cited}

Agency for Toxic Substances and Disease Registry, 2007, Arsenic: Agency for Toxic Substances and Disease Registry, Division of Toxicology and Environmental Medicine ToxFAQs, 2 p., accessed December 2012, at http://www. atsdr.cdc. gov/toxfaqs/tf.asp?id=19\&tid=3.

Barringer, J.L., Mumford, Adam, Young, L.Y., Reilly, P.A., Bonin, J.L., and Rosman, Robert, 2010, Pathways for arsenic from sediments to groundwater to streams: Biogeochemical processes in the Inner Coastal Plain, New Jersey, USA: Water Research, v. 44, no. 19, p. 5532-5544.

City of Norman, 2012, Norman water quality concerns: City of Norman, Oklahoma, accessed December 2012, at http://www.normanok.gov/content/norman-water-qualityconcerns. 
Eisler, Ronald, 1988, Arsenic hazards to fish, wildlife, and invertebrates: A synoptic review: U.S. Fish and Wildlife Service Biological Report 85(1.12), 92 p.

Environmental Working Group, 2010, Chromium-6 is widespread in US tapwater: Environmental Working Group, accessed December 2012, at http:/www.ewg.org/ chromium6-in-tap-water.

Fishman, M.J., ed., 1993, Methods of analysis by the U.S. Geological Survey National Water Quality LaboratoryDetermination of inorganic and organic constituents in water and fluvial sediments: U.S. Geological Survey OpenFile Report 93-125, 217 p.

Fishman, M.J., and Friedman, L.C., 1989, Methods for determination of inorganic substances in water and fluvial sediments: U.S. Geological Survey Techniques of WaterResources Investigations, book 5, chap. A1, 545 p.

Garbarino, J.R., 1999, Methods of analysis by the U.S. Geological Survey National Water Quality LaboratoryDetermination of dissolved arsenic, boron, lithium, selenium, strontium, thallium, and vanadium using inductively coupled plasma-mass spectrometry: U.S. Geological Survey Open-File Report 99-093, 31 p.

Garbarino, J.R., and Struzeski, T.M., 1998, Methods of analysis by the U.S. Geological Survey National Water Quality Laboratory-Determination of elements in wholewater digests using inductively coupled plasma-optical emission spectrometry and inductively coupled plasmamass spectrometry: U.S. Geological Survey Open-File Report 98-165, 101 p.

Garbarino, J.R., and Damrau, D.L.,2001, Methods of analysis by the U.S. Geological Survey National Water Quality Laboratory-Determination of organic plus inorganic mercury in filtered and unfiltered natural water with cold vapor-atomic fluorescence spectrometry: U.S. Geological Survey Water-Resources Investigations Report 01-4132, $16 \mathrm{p}$.

Garbarino, J.R., Bednar, A.J., and Burkhardt, M.R., 2002, Methods of analysis by the U.S. Geological Survey National Water Quality Laboratory-Arsenic speciation in naturalwater samples using laboratory and field methods: U.S. Geological Survey Water-Resources Investigations Report 02-4144, $40 \mathrm{p}$.

Garbarino, J.R., Kanagy, L.K., and Cree, M.E., 2006, Determination of elements in natural water, biota, sediment and soil samples using collision/reaction cell inductively coupled plasma-mass spectrometry: U.S. Geological Survey Techniques and Methods, book 5, sec. B, chap. 1, 88 p.

Helsel, D.R., and Hirsch, R.M., 1992, Statistical methods in water resources: Amsterdam, Netherlands, Elsevier, 522 p.
Hem, J.D., 1985, Study and interpretation of chemical characteristics of natural water ( $3 \mathrm{~d}$ ed.): U.S. Geological Survey Water-Supply Paper 2254, 263 p.

Hoffman, G.L., Fishman, M.J., and Garbarino, J.R., 1996, Methods of analysis by the U.S. Geological Survey National Water Quality Laboratory-In-bottle acid digestion of whole-water samples: U.S. Geological Survey Open-File Report 96-225, 28 p.

Hughes, M.F., 2002, Arsenic toxicity and potential mechanisms of action: Toxicology Letters, v. 133, issue 1, p. 1-16, accessed October 24, 2012, at http:/www. sciencedirect.com/science/article/pii/S037842740200084X.

Izbicki, J.A., Ball, J.W., Bullen, T.D., and Sutley, S.J., 2008, Chromium, chromium isotopes, and selected trace elements, western Mojave Desert, USA: Applied Geochemistry, v. 23, p. 1325-1352.

Jenkins, Ron, Gould, R.W., and Gedcke, Dale, 1995, Quantitative x-ray spectrometry, 2d ed.: New York, Marcel Decker, Inc., 484 p.

Kobayashi, Shigeru, and Lee, G.G., 1978, Accumulation of arsenic in sediments of lakes treated with sodium arsenite: Environmental Science and Technology, v. 12, p. 11951200.

Morales, K.H., Ryan, L., Kuo, T.L., Wu, M.M., and Chen. C.J., 2000, Risk of internal cancers from arsenic in drinking water: Environmental Health Perspectives, v. 108, p. 655-661.

Oklahoma Climatological Survey, 2012, Data summaries: Oklahoma Climatological Survey, accessed October 2012, at http://www.mesonet.org/index.php/site/about/daily_ summaries.

Oklahoma Water Resources Board, 2012, Data and resources, surface water, OWRB streams $(100 \mathrm{~K})$ : Oklahoma Water Resources Board, accessed October 2012, at http://www. owrb.ok.gov/maps/pmg/owrbdata_SW.html.

Parkhurst, D.L., Christenson, Scott, and Breit, G.N., 1996, Ground-water-quality assessment of the Central Oklahoma aquifer, Oklahoma: Geochemical and geohydrologic investigations: U.S. Geological Survey Water-Supply Paper 2347-C, $101 \mathrm{p}$.

Pierce, M.L., and Moore, C.B., 1980, Adsorption of arsenite on amorphous iron hydroxide from dilute aqueous solution: Environmental Science and Technology, v. 14, p. 214-216.

Pritt, J.W., and Raese, J.W., 1995, Quality assurance/quality control manual-National Water Quality Laboratory: U.S. Geological Survey Open-File Report 94-26, 15 p.

Rai, Dhanpat, and Zachara, J.M., 1984, Chemical attenuation rates, coefficients, and constants in leachate migration, vol. 1: A critical review: Electric Power Research Institute EA-3356, variously paged. 
Rantz, S.E., and others, 1982, Measurement and computation of streamflow_-Volume 2, computation of discharge: U.S. Geological Survey, Water-Supply Paper 2175, v. 2, 285 p.

Schlottmann, J.L., Mosier, E.L., and Breit, G.N., 1998, Arsenic, chromium, selenium, and uranium in the Central Oklahoma aquifer, in Ground-water-quality assessment of the Central Oklahoma aquifer, Oklahoma: Results of investigations, 1985: U.S. Geological Survey Water-Supply Paper 2357-A, p. 119-179.

Smith, S.J., 2005, Naturally occurring arsenic in ground water, Norman, Oklahoma, 2004, and remediation options for produced water: U.S. Geological Survey Fact Sheet 2005-3111, 4 p., accessed October 2012, at http://pubs.usgs. gov/fs/2005/3111/.

Smith, S.J., Paxton, S.T., Christenson, Scott, Puls, R.W., and Greer, J.R., 2009, Flow contribution and water quality with depth in a test hole and public-supply wells-Implications for arsenic remediation through well modification, Norman, Oklahoma, 2003-2006: U.S. Environmental Protection Agency Report 600/R-09/036, 147 p., accessed March 22, 2013, at http://www.epa.gov/nrmrl/pubs/600r09036.html.

Smith, S.J., and Becker, C.J., 2011, Characterizing contaminant concentrations with depth by using the USGS well profiler in Oklahoma, 2003-9: U.S. Geological Survey Fact Sheet 2011-3054, 4 p., accessed October 2012, at http://pubs.usgs.gov/fs/2011/3054/.

Stollenwerk, K.G., 2003, Geochemical processes controlling transport of arsenic in groundwater: A review of adsorption, in Welch, A.W., and Stollenwerk, K.G. (eds.), Arsenic in groundwater, geochemistry and occurrence: Boston, Kluwer Academic Publishers, p. 72-92.

TIBCO Software, 2008, Spotfire, What's new in Version 8.1: TIBCO Software, accessed March 22, 2013, at http:// spotfire.tibco.com/ /media/content-center/datasheets/whatsnew-splus-8-1.ashx.

Tiemann, Mary, 2001, Arsenic in drinking water: Recent regulatory developments and issues: National Council for Science and the Environment, updated May 1, 2007, 6 p., accessed October 18, 2012, at www.fas.org/sgp/crs/misc/ RS20672.pdf.

U.S. Army Corps of Engineers, 2012, NRMO2: Lake Thunderbird, accessed February 4, 2013 at http://www. swt-wc.usace.army.mil/THUN.lakepage.html.

U.S. Department of Agriculture, 2010, Aerial photographs: Farm Service Agency National Agricultural Inventory (NAIP) project, June 2010, accessed December 2010, at http://datagateway.nrcs.usda.gov/.
U.S. Environmental Protection Agency, 1980, Ambient water quality criteria for arsenic: U.S. Environmental Protection Agency Report 440/5-80-021, 205 p.

U.S. Environmental Protection Agency, 1985, Ambient water quality criteria for arsenic-1984: U.S. Environmental Protection Agency Report 440/5-84-033, 66 p.

U.S. Environmental Protection Agency, 2006, National recommended water quality criteria: U.S. Environmental Protection Agency, 24 p.

U.S. Environmental Protection Agency, 2007, Field portable $\mathrm{X}$-ray fluorescence spectrometry for the determination of elemental concentrations in soil and sediment, Revision 0: U.S. Environmental Protection Agency, 32 p., accessed October 18, 2012, at www.epa.gov/osw/hazard/testmethods/ sw846/pdfs/6200.pdf.

U.S. Environmental Protection Agency, 2012, Drinking water contaminants: U.S. Environmental Protection Agency, accessed October 18, 2012, at http://water.epa.gov/drink/ contaminants/index.cfm\#List.

U.S. Geological Survey, 2012a, Current conditions for Oklahoma: Streamflow: U.S. Geological Survey, accessed October 24, 2012, at http://waterdata.usgs.gov/ok/nwis/ current/?type=flow\&group_key=NONE.

U.S. Geological Survey, 2012b, USGS water-quality data for Oklahoma: U.S. Geological Survey, accessed October 24, 2012, at http://waterdata.usgs.gov/ok/nwis/qw/.

U.S. Geological Survey, 2012c, Welcome to Streamstats, Oklahoma: U.S. Geological Survey, accessed October 24, 2012, at http://water.usgs.gov/osw/streamstats/oklahoma. html.

Welch, A.H., Westjohn, D.B., Helsel, D.R., and Wanty, R.B., 2000, Arsenic in ground water of the United States: Occurrence and geochemistry: Ground Water, v. 38, no. 4, p. 589-604.

Wilcoxon, Frank, 1945, Individual comparisons by ranking methods: Biometrics Bulletin, v. 1, p. 80-83.

Wilde, F.D., Radtke, D.B., Lane, S.L., Fay, R.G., Gibs, Jacob, Iwatsubo, R.T, and Flanagan, Sarah, (eds.), 2012, National Field Manual for the Collection of Water-Quality Data Techniques of Water-Resources Investigations, Book 9: Handbooks for Water-Resources Investigations Chapters A-1 through A-9, accessed on October 18, 2012 at http://water.usgs.gov/owq/FieldManual/. 



\section{Appendixes}





\section{Appendix 1. Quality Control and Assurance}

Quality-control samples are used for quality assurance, which quantifies reproducibility and reliability of field data. Field water and streambed-sediment samples were collected using protocols described in Wilde and others (2012) and streamflow measurements were made using protocols described in Rantz and others (1982). Sample analyses were done using methods and equipment described in published USGS reports and USEPA methods. The NWQL and USGS Sediment Laboratory routinely run calibration standards, spikes, and blanks for quality-control purposes (Pritt and Raese, 1995).

In addition to quality-control procedures of those laboratories, all streambed-sediment samples were analyzed twice by XRF to account for heterogeneity of metals contents in those samples, and two field-replicate water samples and one field-blank water sample were analyzed for the same constituents as field-water samples. Relative percent difference (RPD) between replicate samples was computed as follows:

$$
\mathrm{RPD}=(|a-b| /(a+b / 2))^{*} 100 \text { percent }
$$

where

$a \quad$ is the trace-element concentration analyzed in the first analysis, and

$b \quad$ is the trace-element concentration analyzed in the second analysis.

RPDs of replicate samples typically were less than 10 percent (tables A1-1 and A1-2), indicating good reproducibility of data. RPDs of constituents measured in replicate well-water samples were slightly greater than those of surface-water samples, which may have been caused by

Table A1-1. Relative percent differences of selected traceelement concentrations in 36 pairs of field and field replicate streambed-sediment samples collected in Norman, Oklahoma, May-June 2012.

[RPD, relative percent difference]

\begin{tabular}{lccc}
\hline Constituent & Sample medium & $\begin{array}{c}\text { Median } \\
\text { RPD }\end{array}$ & $\begin{array}{c}\text { Range } \\
\text { of RPDs }\end{array}$ \\
\hline \multicolumn{2}{c}{ Relative percent differences between replicate analyses } \\
\hline Arsenic & Streambed sediment & 20.8 & $0.0760-119$ \\
Chromium & Streambed sediment & 14.4 & $1.37-200$ \\
Barium & Streambed sediment & 3.2 & $0.146-28.6$ \\
Iron & Streambed sediment & 0.855 & $0.00657-13.7$ \\
Manganese & Streambed sediment & 3.13 & $0.0718-27.0$ \\
\hline
\end{tabular}

relatively high pumping rates and heterogeneous contributions of producing zones of those wells with time. Most constituents analyzed in the field blank water sample were not detected (table A1-3). Constituents detected in the blank sample (total barium, and dissolved iron) were detected at concentrations substantially less than those typically measured in river-water samples.

Table A1-2. Relative percent differences of selected constituent concentrations in one pair of field and field replicate well-water samples and one pair of field and field replicate surface-water samples collected in Norman, Oklahoma, May-June 2012.

[RPD, relative percent difference; "Dissolved" refers to filtered sample and "Total" refers to an unfiltered sample; RPDs not calculated for data pairs with one censored value, designated by "NA"; SW, surface water; WW, well water]

\begin{tabular}{|c|c|c|}
\hline Constituent & $\begin{array}{l}\text { Sample } \\
\text { medium }\end{array}$ & RPD \\
\hline Hardness as calcium carbonate & WW & 3.33 \\
\hline Dissolved phosphorus & $\mathrm{SW} \backslash \mathrm{WW}$ & $2.82 \backslash 0$ \\
\hline Dissolved calcium & $\mathrm{SW} \backslash \mathrm{WW}$ & $1.08 \backslash 3.08$ \\
\hline Total calcium & $\mathrm{SW} \backslash \mathrm{WW}$ & $1.32 \backslash 1.58$ \\
\hline Dissolved magnesium & $\mathrm{SW} \backslash \mathrm{WW}$ & $0.56 \backslash 3.24$ \\
\hline Total magnesium & $\mathrm{SW} \backslash \mathrm{WW}$ & $0.56 \backslash 1.51$ \\
\hline Dissolved arsenic & $\mathrm{SW} \backslash \mathrm{WW}$ & $0 \backslash 0.21$ \\
\hline Total arsenic & $\mathrm{SW} \backslash \mathrm{WW}$ & $0 \backslash 0.22$ \\
\hline Dissolved arsenate & WW & 10.2 \\
\hline Dissolved arsenite & WW & 0 \\
\hline Dissolved dimethylarsinate & WW & 0 \\
\hline Dissolved monomethylarsonate & WW & 0 \\
\hline Dissolved aluminum & $\mathrm{SW} \backslash \mathrm{WW}$ & $44.4 \backslash 8.33$ \\
\hline Total aluminum & $\mathrm{SW} \backslash \mathrm{WW}$ & $16.9 \backslash 6.15$ \\
\hline Dissolved barium & $\mathrm{SW} \backslash \mathrm{WW}$ & $1.93 \backslash 1.87$ \\
\hline Total barium & $\mathrm{SW} \backslash \mathrm{WW}$ & $0.59 \backslash 3.7$ \\
\hline Dissolved chromium & $\mathrm{SW} \backslash \mathrm{WW}$ & $0 \backslash 0.52$ \\
\hline Total chromium & $\mathrm{SW} \backslash \mathrm{WW}$ & $9.52 \backslash 0.49$ \\
\hline Dissolved iron & $\mathrm{SW} \backslash \mathrm{WW}$ & $13.8 \backslash \mathrm{NA}$ \\
\hline Total iron & $\mathrm{SW} \backslash \mathrm{WW}$ & $14.1 \backslash 23.0$ \\
\hline Dissolved manganese & $\mathrm{SW} \backslash \mathrm{WW}$ & $19.4 \backslash 22.9$ \\
\hline Total manganese & $\mathrm{SW} \backslash \mathrm{WW}$ & $2.75 \backslash \mathrm{NA}$ \\
\hline Dissolved selenium & $\mathrm{SW} \backslash \mathrm{WW}$ & $1.00 \backslash 0.59$ \\
\hline Total selenium & $\mathrm{SW} \backslash \mathrm{WW}$ & $1.04 \backslash 1.36$ \\
\hline Dissolved vanadium & $\mathrm{SW} \backslash \mathrm{WW}$ & $6.82 \backslash 0.60$ \\
\hline Total vanadium & $\mathrm{SW} \backslash \mathrm{WW}$ & $2.35 \backslash 0.61$ \\
\hline Total alpha-emitting isotopes of radium & $\mathrm{SW} \backslash \mathrm{WW}$ & $42.5 \backslash 3.08$ \\
\hline
\end{tabular}


Table A1-3. Constituent concentrations measured in field blank water sample collected at the Little River near Franklin, Oklahoma, streamflow-gaging station on April 19, 2012.

[mg/L, milligrams per liter; <, less than; $\mu \mathrm{g} / \mathrm{L}$, micrograms per liter]

\begin{tabular}{lc}
\hline \multicolumn{1}{c}{ Constituent } & $\begin{array}{c}\text { Constituent } \\
\text { concentration }\end{array}$ \\
\hline Dissolved phosphorus, in mg/L & $<0.004$ \\
Dissolved calcium, in mg/L & $<0.022$ \\
Total calcium, in mg/L & $<0.021$ \\
Dissolved magnesium, in $\mathrm{mg} / \mathrm{L}$ & $<0.011$ \\
Total magnesium, in mg/L & $<0.007$ \\
Dissolved arsenic, in $\mu \mathrm{g} / \mathrm{L}$ & $<0.03$ \\
Total arsenic, in $\mu \mathrm{g} / \mathrm{L}$ & $<0.28$ \\
Dissolved barium, in $\mu \mathrm{g} / \mathrm{L}$ & $<0.07$ \\
Total barium, in $\mu \mathrm{g} / \mathrm{L}$ & 0.15 \\
Dissolved chromium, in $\mu \mathrm{g} / \mathrm{L}$ & $<0.60$ \\
Total chromium, in $\mu \mathrm{g} / \mathrm{L}$ & $<0.60$ \\
Dissolved iron, in $\mu \mathrm{g} / \mathrm{L}$ & 0.21 \\
Total iron, in $\mu \mathrm{g} / \mathrm{L}$ & $<0.40$ \\
Dissolved vanadium, in $\mu \mathrm{g} / \mathrm{L}$ & $<0.60$ \\
Total vanadium, in $\mu \mathrm{g} / \mathrm{L}$ & $<0.60$ \\
Dissolved aluminum, in $\mu \mathrm{g} / \mathrm{L}$ & $<2.2$ \\
Total aluminum, in $\mathrm{mg} / \mathrm{L}$ & $<3.8$ \\
Dissolved selenium, in $\mu \mathrm{g} / \mathrm{L}$ & $<0.03$ \\
Total selenium, in $\mu \mathrm{g} / \mathrm{L}$ & $<0.05$ \\
\hline
\end{tabular}


Appendix 2. Stream Distances, MovingAverage Stream Velocities, and Arrival Times from the Upstream Streamflow-Gaging Station (12th Avenue Northwest) Water-Quality Sampling of the Little River near Norman, Oklahoma, May 2012

Table A2-1. Stream distances, moving-average stream velocities, and arrival times from the upstream streamflow-gaging station (12th Avenue Northwest) during the May 8, 2012, sampling event of the Little River near Norman, Oklahoma.

[Start time 17:30 on May 8, 2012; ft, feet; hr, hour; 12th Avenue NW, Little River at 12th Avenue NW near Norman Okla.; 12th Avenue NE, Little River at 12th Avenue Northeast near Norman, Okla.; 36th Avenue NE, Little River at 36th Avenue Northeast near Norman, Okla.; near Franklin, Little River near Franklin, Okla.]

\begin{tabular}{|c|c|c|c|c|c|}
\hline $\begin{array}{l}\text { Sampling } \\
\text { station }\end{array}$ & $\begin{array}{c}\text { Stream } \\
\text { distance } \\
\text { (ft) }\end{array}$ & $\begin{array}{l}\text { Moving } \\
\text { average } \\
\text { velocity } \\
\text { (ft/hr) }\end{array}$ & Hours & Days & $\begin{array}{c}\text { Arrival from } \\
\text { 12th Avenue NW }\end{array}$ \\
\hline \multirow{10}{*}{$\begin{array}{l}\text { 12th } \\
\text { Avenue } \\
\text { NW }\end{array}$} & 0 & 630 & 0.0 & 0.0 & $5 / 8 / 201217: 30$ \\
\hline & 1,640 & 630 & 2.6 & 0.1 & 5/8/2012 20:06 \\
\hline & 3,280 & 630 & 5.2 & 0.2 & 5/8/2012 22:42 \\
\hline & 4,920 & 630 & 7.8 & 0.3 & $5 / 9 / 20121: 18$ \\
\hline & 6,560 & 630 & 10.4 & 0.4 & $5 / 9 / 20123: 54$ \\
\hline & 8,200 & 630 & 13.0 & 0.5 & $5 / 9 / 20126: 30$ \\
\hline & 9,840 & 900 & 14.8 & 0.6 & 5/9/2012 8:20 \\
\hline & 11,500 & 900 & 16.7 & 0.7 & 5/9/2012 10:09 \\
\hline & 13,100 & 900 & 18.5 & 0.8 & 5/9/2012 11:58 \\
\hline & 14,800 & 900 & 20.3 & 0.8 & 5/9/2012 13:48 \\
\hline \multirow{10}{*}{$\begin{array}{l}\text { 12th } \\
\text { Avenue } \\
\text { NE }\end{array}$} & 16,400 & 900 & 22.1 & 0.9 & $5 / 9 / 201215: 37$ \\
\hline & 18,000 & 900 & 23.9 & 1.0 & $5 / 9 / 201217: 26$ \\
\hline & 19,700 & 900 & 25.8 & 1.1 & 5/9/2012 19:16 \\
\hline & 21,300 & 900 & 27.6 & 1.1 & 5/9/2012 21:05 \\
\hline & 23,000 & 900 & 29.4 & 1.2 & $5 / 9 / 201222: 54$ \\
\hline & 24,600 & 900 & 31.2 & 1.3 & $5 / 10 / 20120: 44$ \\
\hline & 26,200 & 756 & 33.4 & 1.4 & $5 / 10 / 20122: 54$ \\
\hline & 27,900 & 756 & 35.6 & 1.5 & 5/10/2012 5:04 \\
\hline & 29,500 & 756 & 37.7 & 1.6 & $5 / 10 / 20127: 14$ \\
\hline & 31,200 & 756 & 39.9 & 1.7 & 5/10/2012 9:24 \\
\hline
\end{tabular}

Table A2-1. Stream distances, moving-average stream velocities, and arrival times from the upstream streamflow-gaging station (12th Avenue Northwest) during the May 8, 2012, sampling event of the Little River near Norman, Oklahoma.-Continued

[Start time 17:30 on May 8, 2012; ft, feet; hr, hour; 12th Avenue NW, Little River at 12th Avenue NW near Norman Okla.; 12th Avenue NE, Little River at 12th Avenue Northeast near Norman, Okla.; 36th Avenue NE, Little River at 36th Avenue Northeast near Norman, Okla.; near Franklin, Little River near Franklin, Okla.]

\begin{tabular}{cccccc}
\hline $\begin{array}{c}\text { Sampling } \\
\text { station }\end{array}$ & $\begin{array}{c}\text { Stream } \\
\text { distance } \\
\text { (ft) }\end{array}$ & $\begin{array}{c}\text { Moving } \\
\text { average } \\
\text { velocity } \\
\text { (ft/hr) }\end{array}$ & Hours & Days & $\begin{array}{c}\text { Arrival from } \\
\text { 12th Avenue NW }\end{array}$ \\
\hline 36th & 32,800 & 756 & 42.1 & 1.8 & $5 / 10 / 201211: 35$ \\
Avenue & & & & & \\
NE & & & & & \\
& 34,500 & 756 & 44.3 & 1.8 & $5 / 10 / 201213: 45$ \\
& 36,100 & 756 & 46.4 & 1.9 & $5 / 10 / 201215: 55$ \\
& 37,700 & 756 & 48.6 & 2.0 & $5 / 10 / 201218: 05$ \\
& 39,400 & 756 & 50.8 & 2.1 & $5 / 10 / 201220: 15$ \\
& 41,000 & 756 & 52.9 & 2.2 & $5 / 10 / 201222: 25$ \\
& 42,600 & 756 & 55.1 & 2.3 & $5 / 11 / 20120: 36$ \\
& 44,300 & 756 & 57.3 & 2.4 & $5 / 11 / 20122: 46$ \\
& 45,900 & 846 & 59.2 & 2.5 & $5 / 11 / 20124: 42$ \\
& 47,600 & 846 & 61.1 & 2.5 & $5 / 11 / 20126: 38$ \\
& 49,200 & 846 & 63.1 & 2.6 & $5 / 11 / 20128: 35$ \\
& 50,900 & 846 & 65.0 & 2.7 & $5 / 11 / 201210: 31$ \\
Franklin & 55,800 & 846 & 70.8 & 3.0 & $5 / 11 / 201216: 20$ \\
\hline Near & 54,500 & 846 & 67.0 & 2.8 & $5 / 11 / 201212: 27$ \\
& 54,100 & 846 & 68.9 & 2.9 & $5 / 11 / 201214: 24$ \\
\hline & & & & & \\
\hline
\end{tabular}


Table A2-2. Stream distances, moving-average stream velocities, and arrival times from the upstream streamflow-gaging station (12th Avenue Northwest) during the May 14, 2012, sampling event of the Little River near Norman, Oklahoma.

[Start time 09:30 on May 14, 2012; ft, feet; hr, hour; 12th Avenue NW, Little River at 12th Avenue Northwest near Norman Okla.; 12th Avenue NE, Little River at 12th Avenue Northeast near Norman, Okla.; 36th Avenue NE, Little River at 36th Avenue Northeast near Norman, Okla. ; near Franklin, Little River near Franklin, Okla.]

\begin{tabular}{|c|c|c|c|c|c|}
\hline $\begin{array}{l}\text { Sampling } \\
\text { station }\end{array}$ & $\begin{array}{l}\text { Stream } \\
\text { distance } \\
\text { (ft) }\end{array}$ & $\begin{array}{c}\text { Moving } \\
\text { average } \\
\text { velocity } \\
\text { (ft/hr) }\end{array}$ & Hours & Days & $\begin{array}{c}\text { Arrival from 12th } \\
\text { Avenue NW }\end{array}$ \\
\hline \multirow{10}{*}{$\begin{array}{l}\text { 12th } \\
\text { Avenue } \\
\text { NW }\end{array}$} & 0 & 1,260 & 0.0 & 0.0 & $5 / 14 / 20129: 30$ \\
\hline & 1,640 & 1,260 & 1.3 & 0.1 & $5 / 14 / 201210: 48$ \\
\hline & 3,280 & 1,260 & 2.6 & 0.1 & $5 / 14 / 201212: 06$ \\
\hline & 4,920 & 1,260 & 3.9 & 0.2 & $5 / 14 / 2012 \quad 13: 24$ \\
\hline & 6,560 & 1,260 & 5.2 & 0.2 & $5 / 14 / 2012 \quad 14: 42$ \\
\hline & 8,200 & 1,260 & 6.5 & 0.3 & $5 / 14 / 201216: 00$ \\
\hline & 9,840 & 960 & 8.2 & 0.3 & $5 / 14 / 2012 \quad 17: 42$ \\
\hline & 11,500 & 960 & 9.9 & 0.4 & $5 / 14 / 201219: 25$ \\
\hline & 13,100 & 960 & 11.6 & 0.5 & 5/14/2012 21:07 \\
\hline & 14,800 & 960 & 13.3 & 0.6 & $5 / 14 / 201222: 50$ \\
\hline \multirow{10}{*}{$\begin{array}{l}\text { 12th } \\
\text { Avenue } \\
\text { NE }\end{array}$} & 16,400 & 960 & 15.0 & 0.6 & $5 / 15 / 20120: 32$ \\
\hline & 18,000 & 960 & 16.8 & 0.7 & $5 / 15 / 20122: 15$ \\
\hline & 19,700 & 960 & 18.5 & 0.8 & 5/15/2012 3:57 \\
\hline & 21,300 & 960 & 20.2 & 0.8 & $5 / 15 / 20125: 40$ \\
\hline & 23,000 & 960 & 21.9 & 0.9 & $5 / 15 / 20127: 22$ \\
\hline & 24,600 & 960 & 23.6 & 1.0 & 5/15/2012 9:05 \\
\hline & 26,200 & 516 & 26.8 & 1.1 & $5 / 15 / 201212: 16$ \\
\hline & 27,900 & 516 & 29.9 & 1.2 & $5 / 15 / 201215: 26$ \\
\hline & 29,500 & 516 & 33.1 & 1.4 & 5/15/2012 18:37 \\
\hline & 31,200 & 516 & 36.3 & 1.5 & $5 / 15 / 201221: 48$ \\
\hline \multirow{14}{*}{$\begin{array}{l}\text { 36th } \\
\text { Avenue } \\
\text { NE }\end{array}$} & 32,800 & 516 & 39.5 & 1.6 & $5 / 16 / 20120: 58$ \\
\hline & 34,500 & 516 & 42.7 & 1.8 & 5/16/2012 4:09 \\
\hline & 36,100 & 516 & 45.8 & 1.9 & 5/16/2012 7:20 \\
\hline & 37,700 & 516 & 49.0 & 2.0 & $5 / 16 / 201210: 31$ \\
\hline & 39,400 & 516 & 52.2 & 2.2 & 5/16/2012 13:41 \\
\hline & 41,000 & 516 & 55.4 & 2.3 & $5 / 16 / 201216: 52$ \\
\hline & 42,600 & 516 & 58.6 & 2.4 & $5 / 16 / 201220: 03$ \\
\hline & 44,300 & 516 & 61.7 & 2.6 & $5 / 16 / 201223: 13$ \\
\hline & 45,900 & 450 & 65.4 & 2.7 & $5 / 17 / 20122: 52$ \\
\hline & 47,600 & 450 & 69.0 & 2.9 & $5 / 17 / 20126: 31$ \\
\hline & 49,200 & 450 & 72.7 & 3.0 & 5/17/2012 10:09 \\
\hline & 50,900 & 450 & 76.3 & 3.2 & $5 / 17 / 201213: 48$ \\
\hline & 52,500 & 450 & 80.0 & 3.3 & $5 / 17 / 2012 \quad 17: 27$ \\
\hline & 54,100 & 450 & 83.6 & 3.5 & $5 / 17 / 201221: 05$ \\
\hline $\begin{array}{l}\text { Near } \\
\text { Franklin }\end{array}$ & 55,800 & 450 & 87.2 & 3.6 & $5 / 18 / 20120: 44$ \\
\hline
\end{tabular}

Table A2-3. Stream distances, moving-average stream velocities, and arrival times from the upstream streamflow-gaging station (12th Avenue Northwest) during the May 17, 2012, sampling event of the Little River near Norman, Oklahoma.

[Start time 16:00 on May 17, 2012; ft, feet; hr, hour; 12th Avenue NW, Little River at 12th Avenue Northwest near Norman Okla.; 12th Avenue NE, Little River at 12th Avenue Northeast near Norman, Okla.; 36th Avenue NE, Little River at 36th Avenue Northeast near Norman, Okla.; near Franklin, Little River near Franklin, Okla.]

\begin{tabular}{|c|c|c|c|c|c|}
\hline $\begin{array}{l}\text { Sampling } \\
\text { station }\end{array}$ & $\begin{array}{c}\text { Stream } \\
\text { distance } \\
\text { (ft) }\end{array}$ & $\begin{array}{c}\text { Moving } \\
\text { average } \\
\text { velocity } \\
\text { (ft/hr) }\end{array}$ & Hours & Days & $\begin{array}{c}\text { Arrival from 12th } \\
\text { Avenue NW }\end{array}$ \\
\hline \multirow{10}{*}{$\begin{array}{l}\text { 12th } \\
\text { Avenue } \\
\text { NW }\end{array}$} & 0 & 756 & 0.0 & 0.0 & 5/17/2012 16:00 \\
\hline & 1,640 & 756 & 2.2 & 0.1 & $5 / 17 / 201218: 10$ \\
\hline & 3,280 & 756 & 4.3 & 0.2 & $5 / 17 / 201220: 20$ \\
\hline & 4,920 & 756 & 6.5 & 0.3 & $5 / 17 / 201222: 30$ \\
\hline & 6,560 & 756 & 8.7 & 0.4 & 5/18/2012 0:40 \\
\hline & 8,200 & 756 & 10.8 & 0.5 & $5 / 18 / 20122: 50$ \\
\hline & 9,840 & 588 & 13.6 & 0.6 & $5 / 18 / 20125: 38$ \\
\hline & 11,500 & 588 & 16.4 & 0.7 & $5 / 18 / 20128: 25$ \\
\hline & 13,100 & 588 & 19.2 & 0.8 & $5 / 18 / 2012 \quad 11: 12$ \\
\hline & 14,800 & 588 & 22.0 & 0.9 & 5/18/2012 14:00 \\
\hline \multirow{10}{*}{$\begin{array}{l}\text { 12th } \\
\text { Avenue } \\
\text { NE }\end{array}$} & 16,400 & 588 & 24.8 & 1.0 & $5 / 18 / 201216: 47$ \\
\hline & 18,000 & 588 & 27.6 & 1.1 & $5 / 18 / 2012$ 19:34 \\
\hline & 19,700 & 588 & 30.4 & 1.3 & $5 / 18 / 201222: 22$ \\
\hline & 21,300 & 588 & 33.2 & 1.4 & 5/19/2012 1:09 \\
\hline & 23,000 & 588 & 35.9 & 1.5 & 5/19/2012 3:56 \\
\hline & 24,600 & 588 & 38.7 & 1.6 & $5 / 19 / 20126: 44$ \\
\hline & 26,200 & 468 & 42.2 & 1.8 & 5/19/2012 10:14 \\
\hline & 27,900 & 468 & 45.7 & 1.9 & 5/19/2012 13:44 \\
\hline & 29,500 & 468 & 49.3 & 2.1 & $5 / 19 / 2012 \quad 17: 15$ \\
\hline & 31,200 & 468 & 52.8 & 2.2 & 5/19/2012 20:45 \\
\hline \multirow{14}{*}{$\begin{array}{l}\text { 36th } \\
\text { Avenue } \\
\text { NE }\end{array}$} & 32,800 & 468 & 56.3 & 2.3 & $5 / 20 / 20120: 15$ \\
\hline & 34,500 & 468 & 59.8 & 2.5 & $5 / 20 / 20123: 45$ \\
\hline & 36,100 & 468 & 63.3 & 2.6 & $5 / 20 / 20127: 16$ \\
\hline & 37,700 & 468 & 66.8 & 2.8 & 5/20/2012 10:46 \\
\hline & 39,400 & 468 & 70.3 & 2.9 & $5 / 20 / 201214: 16$ \\
\hline & 41,000 & 468 & 73.8 & 3.1 & $5 / 20 / 2012$ 17:46 \\
\hline & 42,600 & 468 & 77.3 & 3.2 & $5 / 20 / 2012$ 21:17 \\
\hline & 44,300 & 468 & 80.8 & 3.4 & 5/21/2012 0:47 \\
\hline & 45,900 & 306 & 86.1 & 3.6 & $5 / 21 / 20126: 08$ \\
\hline & 47,600 & 306 & 91.5 & 3.8 & $5 / 21 / 201211: 30$ \\
\hline & 49,200 & 306 & 96.9 & 4.0 & $5 / 21 / 2012 \quad 16: 52$ \\
\hline & 50,900 & 306 & 102.2 & 4.3 & $5 / 21 / 201222: 13$ \\
\hline & 52,500 & 306 & 107.6 & 4.5 & $5 / 22 / 20123: 35$ \\
\hline & 54,100 & 306 & 112.9 & 4.7 & $5 / 22 / 20128: 56$ \\
\hline $\begin{array}{l}\text { Near } \\
\quad \text { Franklin }\end{array}$ & 55,800 & 306 & 118.3 & 4.9 & $5 / 22 / 201214: 18$ \\
\hline
\end{tabular}


Table A2-4. Stream distances, moving-average stream velocities, and arrival times from the upstream streamflow-gaging station (12th Avenue Northwest) during the May 17, 2012, sampling event of the Little River near Norman, Oklahoma.

[Start time 12:30 on May 22, 2012; ft, feet; hr, hour; 12th Avenue NW, Little River at 12th Avenue Northwest near Norman Okla.; 12th Avenue NE, Little River at 12th Avenue Northeast near Norman, Okla.; 36th Avenue NE, Little River at 36th Avenue Northeast near Norman, Okla.; near Franklin, Little River near Franklin, Okla.]

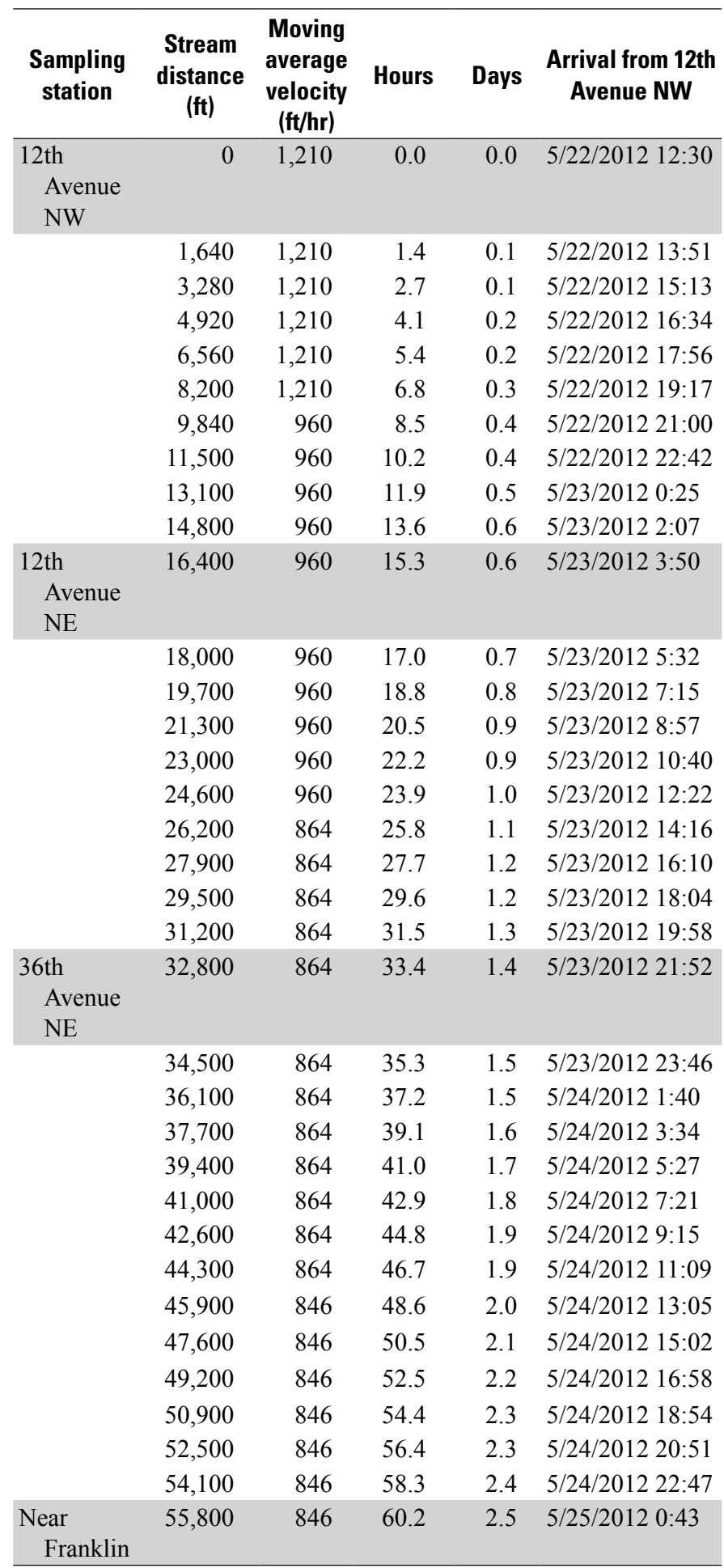


Publishing support provided by Lafayette Publishing Service Center

Information regarding water resources in Oklahoma is available at http://ok.water.usgs.gov/ 


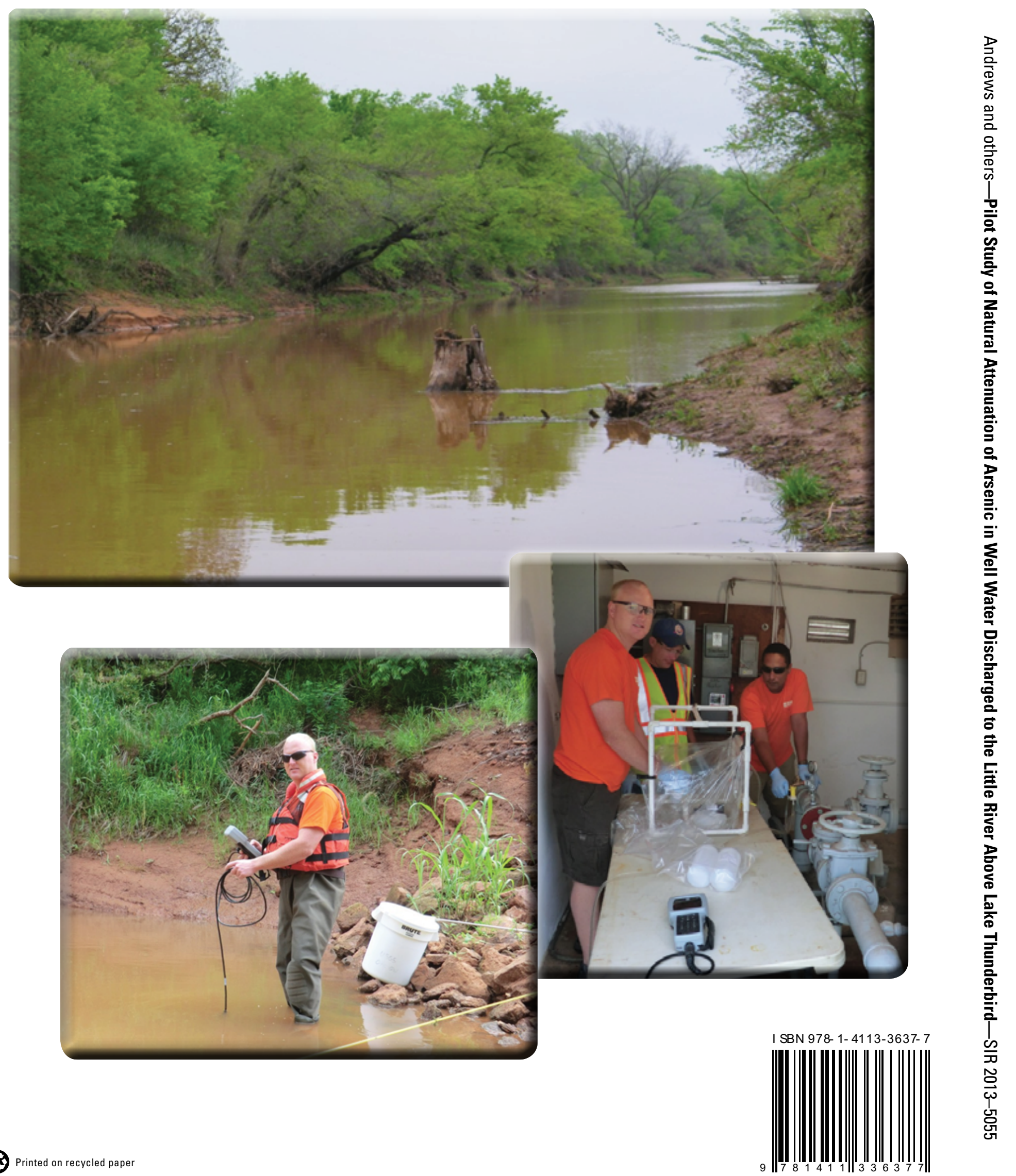

